\title{
II. Meşrutiyet Döneminde İstanbul'da Sosyal Bir Problem Olarak Kumar İlleti
}

\author{
Feyza Kurnaz Şahin*
}

\section{$\ddot{O}_{z}$}

Bu çalışmanın temel amacı, II. Meşrutiyet döneminde İstanbul'da toplumsal hayatı derinden etkileyen kumar illetinin yayginlaşmasının sebeplerini ve Osmanlı Devleti’nin buna yönelik aldığı tedbirleri irdelemek olarak tanımlanır.

II. Meşrutiyet dönemi, kronolojik olarak kısa bir zaman aralığını oluştursa da ekonomik ve toplumsal açıdan birçok sarsıntının yaşandığı, tarihsel açıdan çarpıcı bir süreci ifade eder. Bu dönemde görülen sıra dışlıkta; XIX. yüzyllda başlayan ve XX. yüzyılın ilk çeyreğine kadar süren savaşların etkileri, toprak kayıpları, meşruti yönetimle ilgili yaşanan siyasal gerilimler, özgürlükçü ortam, sosyo-ekonomik krizler, ödenemeyen maaşlar, göçler, Avrupa'nın kültürel ve fiziksel etkisine açık olma durumu etkili olmuştur. Yaşanan sosyal, ekonomik ve siyasal gerilimler toplumu derinden etkilemiş sosyal yapıda çözülmeler baş göstermiştir. Bu dönemde içki, kumar, sefâhat ve fuhuş gibi eylemlerin artışı sosyal çözülmenin varlığına işaret etmektedir.

II. Meşrutiyet döneminde kumar illeti toplumun sosyal ve ahlakî yapısını sarsıcı boyutlara ulaşmıs, aile yapısı zarar görmüş, özellikle memurlar arasında kumarın yayılması devletin itibarını sarsmıştır. Kumarın toplumsal bir hastalığa dönüşmesi Osmanlı hükümetlerinin tedbir almasını gerekli kılmış, ancak yapılan yasal düzenlemeler ve alınan polisiye tedbirler kumarı önleyememiştir.

İstanbul, devletin başkenti olarak mevcut sorunları ve gerilimleri en derinden hisseden şehir olmuştur. XIX. yüzylın ikinci yarısından itibaren Batı tarzı bir başkente dönüşme sancıları çeken şehirde, aynı anda Batılı yaşam tarzı da etkili olmaya başlamıştır. Bu meyanda eğlence hayatı renklenmiş, kulüpler, barlar, lokantalar, gazinolar ve oteller yeni eğlence mekânlarını oluşturmuştur. Osmanlı başkentinin geleneksel dokusu

* Doç. Dr., Afyon Kocatepe Üniversitesi, Atatürk Illkeleri ve İnkılâp Tarihi Bölüm Başkanlığı, Afyonkarahisar/TÜRKIYE, fsahin@aku.edu.tr ORCID: 0000-0002-4858-1639

DOI: 10.37879/belleten.2020.1143

Makale Gönderim Tarihi: 06.01.2019 - Makale Kabul Tarihi: 11.08.2020

Belleten, Aralık 2020, Cilt: 84/Sayı: 301; 1143-1174 
bozulmuş, kahvehanelerde ve diğer mekânlarda içki, kumar ve sefâhat belirgin hale gelmiştir.

Araştırmanın temel kaynağını Cumhurbaşkanlı̆̆ı Devlet Arşivleri Başkanlığı Osmanlı Arşivindeki belgeler oluşturmuştur. İlaveten dönemin süreli yayınlarından yararlanılmıştır.

Anahtar Kelimeler: Kumar, Osmanlı İmparatorluğu, II. Meşrutiyet, Kumar Önleyici Tedbirler, Kahvehane.

\title{
Gambling Malady as a Social Problem during the Second Constitutional Period in Istanbul
}

\begin{abstract}
The primary purpose of this study is to examine the reasons for the spread of gambling malady, which deeply affected social life in Istanbul during the Constitutional Monarchy period and the measures taken by the Ottoman State against gambling.

Although the Second Constitutional Period chronologically constituted a short period of time, it was a historically striking process in which many shocks lived in economic and social terms. The problems encountered in this period were the results of the wars from the $19^{\text {th }}$ century onward, land losses, political tensions related to the constitutional management, libertarian environment, socio-economic crises, non-paid salaries, immigration, and the state of being open to European cultural and physical influence. The social, economic, and political tensions experienced during this period influenced the society deeply, and disintegration appeared in the social structure. Increased actions such as drinking alcohol, gambling, debauchery, and prostitution during this period indicate the existence of social decay.

During the Second Constitutional Period, the gambling malady reached a shaking dimension to the social and moral structure of the society, the family structure was damaged, and the spread of gambling among the civil servants, in particular, undermined the reputation of the state. Gambling, which became a common illness, forced the Ottoman governments to take preventive measures, but the legal regulations and the preventive police measures failed to prevent gambling.

İstanbul, the capital city of the Ottoman Empire, has been the city that felt the existing problems and tensions the most deeply. This city was while experiencing the pains of transformation to become a western-style capital since the second half of the $19^{\text {th }}$ century also hosted to a western lifestyle. In this respect, nightlife was enlivened, and clubs, bars, restaurants, casinos, and hotels formed the new places of entertainment. The traditional pattern of the capital of the Ottoman State was degenerated, and
\end{abstract}


drinking alcohol, gambling, and debauchery became common in coffeehouses and other places.

The primary sources of this study are the documents from the Ottoman Archives of the Presidency. Moreover, periodicals published during this period were used as sources in this study as well.

Keywords: Gambling, Ottoman Empire, Second Constitutional Period, AntiGambling Measures, Coffeehouse.

\section{Giriş}

Kumar; Arapça kökenli "kimâr" kelimesinden gelmekte olup Türk Dil Kurumu sözlüğünde "ortaya para koyarak oynanan talih oyunu" olarak tanımlanır. ${ }^{1}$ Misalli Büyük Türkçe sözlügüunde, "para karşılı̆̆ı ve para kazanmak için oynanan oyun" olarak ifade edilmiştir. ${ }^{2}$ Türk Hukuk Lügatinde ise, "kazanç kastiyle icra kılınan kâr ve zarar, baht ve talihe bağg bulunan oyunlardır" şeklinde belirtilmiştir. ${ }^{3}$ Geniş manada kumar; "şans ve becerinin birlikte veya tek başına söz konusu olduğu bir olay yahut yarş̧manin ya da belirsiz bir olayn sonucu üzerine bahse tutuşma ve bu yolla kazanç elde etme" anlaminı da taşımaktadır. ${ }^{4}$

Çalışmada kullanılan arşiv belgelerinde Osmanlı hükümetlerinin kumarı, sosyal, ekonomik ve ahlaki bir sorun olarak gördüğü tespit edilmiştir. Yazışmalarda devlet adamları suç sayılan kumara bulaşanların ahlakî ve dinî bakımdan da zaafa uğradığını sıklıkla ifade etmiş, kumarın önlenmesi ve kumar suçu işleyenlerin cezalandırılması için de yasal düzenlemeler yapmışlardır. Bu anlamda öncelikli olarak $1851^{5}$ ve 1858 tarihli Ceza Kanununa kumarın suç olduğuna ilişkin esaslar konulmuştur. ${ }^{6}$ Yine 1869 Askerî Geza Kanunnâmesinde kumar oynayan askerlere

1 TDK Türkçe Sözlük, Türk Dil Kurumu Yayınları, 11. bs., Ankara 2011, s. 1524.

2 İlhan Ayverdi, Misalli Büyük Türkçe Sözlük, C 2, Kubbealtı Lugati, 4. bs., İstanbul 2011, s. 1811.

3 Türk Hukuk Lügati, haz.: Türk Hukuk Kurumu, Başbakanlık Mevzuatı Geliştirme ve Yayın Genel Müdürlüğü Yayınları, 3. bs., Ankara 1991, s. 206-207.

4 Ali Bardakoğlu, "Kumar", İslam Ansiklopedisi, C 26, Türkiye Diyanet Vakfi Yayını, İstanbul 2002, s. 364 .

5 Ahmed Lütfi, Mir'at-ı Adalet Yahud Tarihçe-i Adliye-i Devlet-i Aliye, Naşiri: Kitapcı Ohannes, Matbaa-i Nişan Berberyan, İstanbul 1304, s. 127; Ahmet Akgündüz, Mukayeseli Íslam ve Osmanlı Hukuku Külliyatı, Dicle Üniversitesi Hukuk Fakültesi Yay., Diyarbakır 1986, s. 821-831; Mehmet Akif Aydın, "Osmanlı Ceza Hukuku”, İslam Ansiklopedisi, G 7, Türkiye Diyanet Vakfi Yayını, İstanbul 1993, s. 481-482; Mustafa Şentop, "Tanzimat Dönemi Kanunlaştırma Faaliyetleri Literatürü", Türkiye Araştrrmalan Literatür Dergisi, C 3, S. 5, (2005), s. 653.

6 “Ceza Kanunnâme-i Hümâyunu”, 28 Zilhicce 1274/9 Ağustos 1858, Düstur, Tertip I, C I, Mat- 
verilecek cezalar belirlenmiş ve 17 Ağustos 1907 tarihli Polis Nizamnâmesinde de kolluk kuvvetinin kumarla ilgili alması gereken önlemler hakkında hükümler yer almıştır. $^{8}$

Şer’i ve hukuki olarak yasaklanmasına rağmen Osmanlı ülkesinde kumar her dönem görülen bir alışkanlık olmuştur. Ancak savaş dönemlerinin olağanüstü koşullarında bu tür alışkanlıklar yaygınlık kazanmıştır. Bunun yanında ekonomik ve sosyal buhranlar nedeniyle toplumsal yaşantının derinden sarsıldığı süreçlerde, halk arasında sakıncalı olarak görülen kumar, içki, sefâhat ve fuhuş gibi alışkanlıklar artmıştır. Bu cümleden olarak XIX. yüzyılın ikinci yarısından itibaren bu şartların varlığı dikkat çekmektedir. Zira Kırım Savaşı sırasında yaşanan finansal krize bağlı olarak Osmanlı hükümeti orduda bulunan subay ve neferlerin maaşlarını dahi ödeyemeyecek duruma düşmüştür. Bu soruna çözüm bulmak için orduların bulunduğu bölgedeki servet sahibi kişilerden iane toplandığı görülmüştür. Ancak iç kaynaklar savaşın finansmanında yetersiz kalınca savaşın getirdiği yeni masraflar ve bütçe açığı Osmanlı Devleti’ni farklı arayışlara sevk etmiştir. Zor durumda olan Osmanlı maliyesi, savaşın getirmiş olduğu yeni yükleri karşlayabilmek amacıyla tarihinde ilk kez dış borçlanmaya gitmiş̧tir. Ülkenin içinde bulunduğu finansal krize bağlı olarak borçların geri ödemeleri sıkıntıları daha da artırmıştır. ${ }^{9}$ Bu durum toplumsal bazı travmaların yaşanmasına, kumar gibi suç sayılan bazı fillerin aleni hale gelmesine sebep olmuştur.

II. Meşrutiyet döneminde İstanbul'da toplumsal hayatı derinden etkileyen kumar illetinin yaygınlaşmasının sebeplerini ve Osmanlı Devleti’nin buna yönelik aldığı tedbirleri irdelemek çalışmanın temel amacını oluşturmuştur. Bunun yanında ku-

baa-yı Amire, 1289, s. 591; Akgündüz, age, s. 873; Senem Öner, Çeviri Yoluyla Kanun Yapmak: 1858 Tarihli Osmanh Ceza Kanunu'nun 1810 Tarihli Fransız Ceza Kanunu’ndan Çevrilmesi, (Basılmamış Doktora Tezi), Yıldız Teknik Üniversitesi Sosyal Bilimler Enstitüsü, İstanbul 2013, s. Ekler-64.

7 Cumhurbaşkanlığı Devlet Arşivleri Başkanlığı Osmanlı Arşivi (BOA), Şura-yı Devlet Evrakı (ŞD.), nr. 657/58, s. 8, Tarih: 10 Teşrinievvel 1329/23 Ekim 1913.

8 “Polis Nizamnâmesi”, Düstur, Tertip I, Mütemmim, Hilal Matbaası, 15 Muharrem 1269-8 Recep 1325, Dersaadet Zilkade 1335, s. 637; Ali Dikici, "II. Meşrutiyet'ten Cumhuriyet’e Miras Kalan İç Güvenlik Anlayışı ve Polis Teşkilatı", Türk İdare Dergisi, S. 479, (Aralık 2014), s. 95.

9 Osmanlı Belgelerinde Kirm Savaşı (1853-1856), yay.haz., Kemal Gurulkan vd., Devlet Arşivleri Genel Müdürlüğü Yayınları, Ankara 2006, s. 211-213; Şevket Pamuk, Osmanl Imparatorluğu'nda Paramn Tarihi, Tarih Vakfi Yurt Yayınları, İstanbul 1999, s. 231; Necdet Aysal, "Kırım Savaşı'ndan Lozan Barış Antlaşması'na Osmanlı Dış Borçlarının Tarihsel Gelişim Süreci (1854-1923)", Ankara Üniversitesi Türk İnkulâp Tarihi Enstitüsü Atatürk Yolu Dergisi (Lozan Antlaşması Özel Saynsı), S. 53, (2013), s. 6 . 
marın sosyal boyutları hakkında yeterli araştırma bulunmadığından ve bu hususta bilimsel bilgiyi elde etmek gerekli görüldüğünden çalışma bu alandaki boşluğu doldurmak amacıyla yapılmıştır. Araştırmada Cumhurbaşkanlığı Devlet Arşivleri Başkanlığı Osmanlı Arşivi’nde mevcut Babıali Evrak Odası, Dahiliye Nezareti, Yıldız, Maarif ve Şura-yı Devlet evrakı esas alınmıştır. Bunun yanında Sebîlürreşad (Sırat-ı Müstakim), Servet-i Fûnun, Sabah ve Tanin gibi dönemin süreli yayınlarından da yararlanılmıştır.

\section{Osmanlı Toplumunda Kumarın Artışının Nedenleri}

Osmanlı toplumunda XIX. yüzyılın ikinci yarısından itibaren kumarın yaygınlaştığı anlaşılmaktadır. Yaşanan ekonomik sıkıntılar ve savaş koşulları Osmanlı toplumunun gelir dağılımını etkilemiştir. Öte yandan 1853-1856 Kırım Savaşı sırasında Osmanlı başkentine gelen Rus esirler kaldıkları bölgelerde eğlence hayatını değiştirmiş, bu durum kumar alışkanlığını da görünür hale getirmiştir. ${ }^{10}$

Öte yandan 1877-1878 Osmanl-Rus Savaşı sırasında yaşanan finansal krizler, Osmanlı toplumunun sosyal ve ekonomik yapısını derinden etkilemiştir. Savaşta alınan yenilgi, toprak kayıpları, yoğun göç nedeniyle Osmanlı Devleti’nin gelirleri zorunlu giderlerini karşılayamamıştır. ${ }^{11}$ Devlet akın akın gelen göçmen kitlelerinin iaşe, nakil ve iskânını sağlamak zorunda kalmıştır. ${ }^{12}$ Dış borçlanma ve bilahare borçların ödenememesi sonucunda Muharrem Kararnâmesi imzalanmış ve 1881'de Düyûn-u Umûmiye kurularak Osmanlı gelirlerine el konulmuştur. ${ }^{13}$

II. Meşrutiyet döneminde siyasi çalkantıların yanında ekonomik sıkıntılar da yoğun olarak hissedilmiştir. Zira XIX. yüzyıl boyunca süren savaşlar sonucunda zayıflayan Osmanlı Devleti sosyal, ekonomik ve askeri açıdan sıkıntılı bir sürece girmiştir. Yıllarca devam eden savaşlar nedeniyle pek çok işyeri kapanmak zorunda kalmış, göçler nedeniyle işsizlik had safhaya varmıştır. Dış borçlanmanın giderek artması ve yaşanan mali krizler de toplumsal yapıyı sarsmıştır. ${ }^{14}$ Öte yandan II. Meşrutiyet döneminde uygulanan liberal iktisadi politikalar, ticareti yoğunlukla

10 Kemal Yakut - Aydın Yetkin, “II. Meşrutiyet Dönemi’nde Toplumsal Ahlak Bunalımı: Fuhuş Meselesi”, Kebikeç, Yıl 16, S. 31, (2011), s. 275.

11 Aysal, agm., s. 6.

12 Mehmet Demirtaş, "Osmanlıya Gelen Kırım ve Kafkasya Göçmenlerinin Sorunları", Bilig, S. 57, (Bahar 2011), s. 38.

13 Şevket Pamuk, Osmanh-Türkiye İktisadi Tarihi 1500-1914, İletişim Yayınları, 8. bs., İstanbul 2013, s. 230-233.

14 Ahmet Tabakoğlu, Osmanh Mali Tarihi, Dergah Yayınları, İstanbul 2016, s. 790-793. 
elinde bulunduran gayrimüslimler ve yabancı şirketlerin etkinliğini arttırmıştır. Ancak bu durum Müslüman tüccarı olumsuz etkilemiştir. Zira Müslüman tüccar, yabancı şirketlerle rekabet edecek güce sahip olmadı̆̆ için fakirleşmiş, birçok işyeri kapanmış ve işsizlik artmıştır. ${ }^{15}$ Osmanlı Devleti’nin içinde bulunduğu mali zorluklar, siyasal krizler, fiyat artışları, maaş ödemelerinde yaşanan sıkıntılar ve göçler, sosyal çözülmeyi beraberinde getirmiş toplumda suç sayılan fiillerde ciddi bir artış yaşanmıştır. ${ }^{16}$

Sosyal ve ekonomik krizlerin yarattı̆̆ı neticelerin yanında kumar, eğlence, içki ve sefâhat gibi alışkanlıkların artışında yaşam tarzı değişikliklerinin etkisinden de bahsetmek gereklidir. Zira XIX. yüzyılın sonlarına gelindiğinde Osmanlı gündelik yaşam kültüründe önemli değişiklikler yaşanmıştır. ${ }^{17} \mathrm{Bu}$ anlamda İngiltere ve Fransa, Kırım Savaşı sırasında Osmanlı Devleti'nin müttefiki olduğundan bu dönemde İstanbul'a çok sayıda İngiliz ve Fransız subay aileleriyle birlikte gelerek yerleşmiştir. İngiliz ve Fransız askerlerin İstanbul'a yerleşmesi buradaki sosyal mekânları ve eğlence hayatını değiştirmiştir. Osmanlı payitahtında Batılı yaşam tarzına özgü eğlence mekânları açılmaya ve eğlence hayatı renklenmeye başlamıştır. ${ }^{18}$ Batılı yaşam tarzının İstanbul'un bazı bölgelerinde etkili olmasının kumar alışkanlığını tetiklediği açıktır. Zira özellikle İstanbul (sur içi) ve Galata yoğunlukla gayrimüslimlerin ve yabancıların ikamet ettiği bir bölge olmuştur. Öte yandan denizci ve tüccar gibi marjinal gruplar bu bölgedeki bekâr odalarını tercih etmişlerdir. Bölgede çok sayıda genelev ve meyhane faaliyet göstermiştir. Bu şartlardan kaynaklı olarak Galata ve Beyoğlu bölgesinde farklı bir kültürel yapı oluşmuştur. Burada oteller, kahvehaneler, lokantalar, gazinolar, barlar ve kumar kulüpleri yoğunlaşmıştır. Batılı giyim tarzı, tiyatrosu, tüketim alışkanlığı ile Avrupa ve Osmanlı karışımı bir yapıya kavuşan Galata'da kumar da aleni hale gelmiştir. ${ }^{19}$

15 Arzu Varlı - Murat Koraltürk, "II. Meşrutiyet’ten Erken Cumhuriyet'e Milli İktisadın Sürekliliği ve İzmir İktisat Kongresi”, Çağdas Türkiye Tarihi Araştrmalan Dergisi (ÇTTAD), C IX/20-21, (Bahar-Güz 2010), s. 128-129; Ahmet Tabakoğlu, Türkiye İktisat Tarihi, Dergah Yayınları, 11. bs., İstanbul 2012, s. 460-461.

16 Şevket Pamuk, Osmanh Ekonomisinde Bağımllık ve Büyüme 1820-1913, Tarih Vakfi Yurt Yayınları, 2. bs., İstanbul 1994, s. 1-7; Donald Quataert, Osmanl Devleti'nde Avrupa İktisadi Yayzlım ve Direnis 1881-1908, İletişim Yay., İstanbul 2017, s. 225.

17 Suraiya Faroqhi, Osmanh Kültürü ve Gündelik Yaşam Ortaçağgdan Yirminci Yüzylla, Tarih Vakfi Yurt Yayınlar1, 4. bs., İstanbul 2002, s. 288.

18 Mesut Yolal, Osmanh Devleti’nde Şans Oyunlar ve Kumar (1800-1923), (Basılmamış Doktora Tezi), Gaziantep Üniversitesi Sosyal Bilimler Enstitüsü, Gaziantep 2018, s. 40-41.

19 Şafak Tunç, Osmanlı Payitahtında Kahvehane ve Kahvehane Kültürünün Keri, (Basılmamış Yüksek Lisans 
Yaşantıdaki bu değişim Osmanlı basınına da yansımıştır. Bu bağlamda basında sefâhat ve refahın toplumsal ahlakı bozduğuna ilişkin ciddi vurgular yapılmıştır. Örneğin Sebîlürreşad'ın 12 Eylül 1912 tarihli nüshasında Halil Fahreddin tarafindan kaleme alınan yazıda sefâhat düşkünlüğ̈nün bütün toplum kesimlerine bir hastalık gibi yayıldığına ilişkin şu ifadeler yer almıştır;

“Osmanlı memleketi, tevsî' daire ettikçe, sefâhat de olanca kuvvetiyle tevsî' ediyor. Efrâd-ı milletin ahlakı yavaş yavaş bozulmaya başlıyordu. Bu sefâhat efrâd-1 millette olduğu gibi, ekâbire de sirâyet etmiş ve hatta dünyayı zabt etmeyi işten bile addetmeyen padişahları da yed-i tahakkümüne almışdı. İşte sefâhatin sukût-u ahlakın baş gösterdiği bu zamanlarda fütûhat ve terakkî devri yavaş yavaş kapanmağa ve buna mukâbil inhitat devri açılmağa başlamışt. Zaten "hikmet-i tarih" de gösteriyor ki herhangi bir hükümetin inkırâzı mutlaka efrâdının sukût-u ahlaka dûçâr olmasını müteâkiptir". ${ }^{20}$

Kumarın yaygınlaşmasının bir diğger sebebi yasal düzenlemelerin yetersizliğidir. ${ }^{21}$ 1858 tarihli Ceza Kanununun 242. ve 243. Maddelerinin ${ }^{22}$ kumar oynayan kişiye verilecek cezaya ilişkin net hükümler taşımaması, içki ve kumar gibi alışkanlıkları ortadan kaldırmaya yeterli olmaması kumarın illet haline gelmesine neden olmuştur. ${ }^{23}$ Buna yönelik şikâyetler üst düzey yöneticiler tarafindan da zaman zaman

Tezi), İstanbul Üniversitesi Sosyal Bilimler Enstitüsü, İstanbul 2014, s. 38; Yeter Öztürk, XIX. Yüzyl Arşiv Belgelerine Göre Osmanh Devleti’nde İ̧cki ve Yasaklar, (Basılmamış Yüksek Lisans Tezi), Ordu Üniversitesi Sosyal Bilimler Enstitüsü, Ordu 2017, s. 42-43.

20 Halil Fahreddin, "Bizde Ahlak", Sebilüreşad, 30 Ağustos 1328 (12 Eylül 1912), G 9, Adet: 28-210, s. 31; Mustafa Gündüz, II. Meşrutivet'in Klasik Paradigmalar, İctihad, Sebilür' Reşad ve Türk Turdu’nda Toplumsal Tezler, Lotus Yayıları, Ankara 2007, s. 279.

21 BOA, Dahiliye Nezareti İdare Evrakı (DH.ID.), nr. 891/2, s. 001.001, Tarih: Rebiülevvel 1329/ Mart 1911.

22 "Ceza Kanunnâme-i Hümâyunu", 28 Zilhicce 1274/9 Ağustos 1858, Düstur, Tertip I, C I, Matbaa-yı Amire, 1289, s. 591; Akgündüz, a.g.e, s. 873; Öner, agt., s. Ekler-64; Canan Çetinkaya Kadir Kasalak, Cumhuriyet’in Illk Yillarında Piyangoculuk", Sobider Sosyal Bilimler Dergisi, Yıl: 2, S. 5, (Aralık 2015), s. 468; Canan Çetinkaya, Osmanlı'nn Son Dönemleri ve Cumhuriyetin İlk Yillarnnda Şans Oyunlan, (Basılmamış Yüksek Lisans Tezi), Süleyman Demirel Üniversitesi Sosyal Bilimleri Enstitüsü, Isparta 2015, s. 9-10.

23 BOA, ŞD., nr. 2364/001, s. 01, Tarih: 16 Kanunuevvel 1319/10 Şevval 1321/30 Aralık 1903; BOA, DH.ID., nr. 891/2, s. 001.001, Tarih: Rebiülevvel 1329/ Mart 1911; BOA, ŞD., nr. 2364/001, s. 01, Tarih: 16 Kanunuevvel 1319/10 Şevval 1321/30 Aralık 1903; BOA, DH.ID., nr. 891/2, s. 001,001, Tarih: Rebiülevvel 1329/ Mart 1911; BOA, DH.ID., nr. 891/2, s. 001,001, Tarih: Rebiülevvel 1329/ Mart 1911; BOA, DH.ID., nr. 891/2, s. 001,001, Tarih: Rebiülevvel 1329/ Mart 1911; BOA, DH.ID., nr. 891/2, s. 07,001, 08, 01, Tarih: 15 Ağustos 1326/ 28 Ağustos 1910; BOA, DH.İ., nr. 891/02, s. 002,002, 003, 001, 006, 002, Tarih: 10 Ağustos 1326/ 23 Ağustos 1910; BOA, DH.İD., 891/2, s. 07,001, 08, 01, Tarih: 15 Ağustos 1326/ 28 Ağustos 
dile getirilmiştir. Mesela Balkan Savaşları sürecinde askerler arasında içki ve kumarın artması nedeniyle Harbiye Nazırı Ahmet İzzet Paşa cezaların caydırıcı olmasını önermiş ve mevcut kanunda değişikliğe gidilmesi gerektiğini bildirmiştir. ${ }^{24}$

Kolluk kuvvetlerinin kumarı önlemek için yeterli titizliği göstermemesi de kumarın artmasının nedenlerinden birisidir. Osmanlı arşiv belgelerine yansıyan verilerde halk, kumar ve fuhuşun önünün alınamamasından polisi sorumlu tutmuştur. Polisin ihmalkâr davrandığı ve gerekli denetimi yapmadığı bu sebeple de kumarın toplumsal bir hastalık haline geldiği dile getirilmiştir. ${ }^{25}$

\section{Kahvehanelerde Kumar}

Kahvehaneler Osmanlı toplumunda XVI. yüzyıldan itibaren artmaya başlamış ve mahalle kahvelerinin açılmasıyla ev, cami ve çarşı üçgeni içerisinde geçen gündelik yaşama yeni bir mekân eklenmiştir. Kahvehaneler ilerleyen yüzyıllar içerisinde çeşitlenmiş, tulumbacı kahveleri, esnaf kahveleri, semai kahveleri, yeniçeri kahveleri şeklinde kişilerin ilgi ve meslek dallarına göre ayrılmıştır. Kahvehaneler toplumsal hayatı etkileyen mekanlar olduğundan akademik yazında "İstanbul'un tanrısız tapınaklar" olarak ifade edilmiştir. ${ }^{26}$

Kahvehaneler bu özelliklerinin yanında zaman içinde kumar oynanan yerler haline gelmişlerdir. Özellikle kahvehanenin bulunduğu mahalledeki sakinler, kahvehanede kumar oynandığına dair ihbarlarda bulunmuştur. Bu ihbarlar üzerine kahvehanelere baskın düzenlenmiştir. Örneğin Ekim-Kasım 1849 tarihli olup Ayazma mahallesine mensup mahalle sakinlerinin gönderdiği bir arzuhalde, Salih Efendi'nin Üsküdar'da bulunan kahvehanesinde kumar oynattığı ve bu durumun ahalinin rahatını ve mahallenin asayişini bozduğu belirtilerek kahvehanenin kapatılması talep edilmiştir. ${ }^{27}$

Sadrazamlık Mektûbî Kaleminden 29 Mart 1906 tarihinde Zaptiye Nezareti’ne

1910 .

24 BOA, ŞD., nr. 657/58, s. 006, Tarih: 5 Teşrinievvel 1329/17 Zilkade 1331/18 Ekim 1913.

25 BOA, Dahiliye Nezareti Emniyet-i Umûmiye Kısm-1 Adli Kalemi (DH.EUM.KADL.), 2/52, s. 3, (25 Aralık 1910).

26 Ekrem Işın, İstanbul'da Gündelik Hayat, Yapı Kredi Yayınları, İstanbul 1999, s. 273-281, 291-298; Gürsoy Şahin, İngiliz Seyahatnamelerinde Osmanl Toplumu ve Türk Imajı, Gökkubbe Yayınları, İstanbul 2017, s. 122-124.

27 BOA, Divan (Beylikçi) Kalemi Defterleri (A.DVN.), nr. 54/17, Tarih: Zilhicce 1265/ Ekim-KaSim 1849 . 
gönderilen bir belgede de benzer bir durum dile getirilmiştir. Söz konusu belgede çeşitli kişilerin kumar bağlantıları üzerinde durularak kumar için alınması gereken tedbirler sıralanmıştır. Buna göre, Kadıköy İskelebaşı'nda Rum cemaatinden İbsiya adlı bir kişinin daha önce kiralamış olduğu bir kahvehaneyi Kürd Said ve Mustafa adlı kişiler yeniden kiralamak istemiş, Ali Şamil adında bir kişinin aracılık etmesi sonucunda kahvehane kiralanmıştır. Ancak kahvehanede Ali Şamil'in himayesinde kumar oynandığı anlaşılmıştır. Sadrazamlık söz konusu kahvehanenin kapanmasını, Ali Şamil vasıtasıyla oraya kumar oynamaya gelen şahısların tespit edilerek haklarında inceleme başlatılmasını istemiştir. Ayrıca Ali Şamil ile ilişkili olan Tahtalı Nureddin adlı şahsın mahkûm ve sabıkalı olduğunun Üsküdar Mutasarrıflı̆ına haber verilmesi ve mahkûmun yakalanarak tevkif edilmesi istenmiştir. Keza Defter-i Hâkânî Tasdik Kalemi Müdür Muavini İbrahim Bey’in bu kumarhanelerle olan ilişkisinin incelenmesi talep edilmiştir. ${ }^{28}$

Yukarıda ifade edilen sorunları içeren benzer şikâyetler İstanbul'un diğer semtlerinden de gelmiştir. Bu dönemde Aksaray, Beyazıt ve Galata gibi İstanbul'un değişik semtlerinde faaliyet gösteren kahvehanelerde kumar oynatıldığı ile ilgili çok sayıda ihbarnâmeye rastlamak mümkündür. Örneğin 10 Ocak 1911 tarihli olup Emniyet-i Umûmiye Müdüriyetinden İstanbul Birinci Şube'ye gönderilen tezkerede, İstanbul'un çeşitli semtlerinde kahvehanelerde kumar oynatıldığına dair ihbarların geldiği belirtilmiş ve bu ihbarların değerlendirilerek ivedilikle gereğinin yapılması istenmiş̧ir. Gelen şikayetlerde; Aksaray'da tramvay merkezinde bulunan Merkez Kıraathanesinde, Galata'da Hamid Bey Kıraathanesinde, Beyazıt'ta Afitab Kıraathanesinde, Şehzadebaşı'nda Ali Çavuş Kıraathanesinde, Çemberlitaş’ta Abdal Cavid'in Diyarbekir Kıraathanesinde, Galata'da Papaz Köprüsü civarında ve diğer yerlerde faaliyet gösteren bazı kahvehanelerde sabahtan akşama kadar kağıt ve tavla oyunlarıla meşgul olunduğu ve herhangi bir işi bulunmayan kişiler tarafından kumar oynandığı bildirilmiştir. Yine Beyoğlu ve Galata'nın karşı tarafinda bulunan kahvehanelerde ise Yunanlıların kumar oynattıkları, hatta buraya bazı İslam ve Osmanlı Rum serserilerinin devam ettikleri yapılan inceleme sonucunda görülmüştür. Kumar oynandığı haber alınan kahvehanelere İstanbul polisi tarafindan baskın düzenlenmiştir. ${ }^{29}$

Kahvehane sahipleri Polis Müdüriyeti tarafindan yapılan baskınlar sonucunda

BOA, Babıali Evrak Odası Evrakı (BEO), nr. 2796/209665, Tarih: 16 Mart 1322/29 Mart 1906.

BOA, DH.EUM.KADL., nr. 3/18, s. 001, 002, 003, Tarih: 28 Kanunuevvel 1326/10 Ocak 1911 . 
kumar oynatıldığına dair düzenlenen raporlara itiraz etmişlerdir. Kendilerinin uzun yıllar kahvehane işlettiklerini, masum olduklarını, haksızlığa uğradıklarını sıklıkla dile getirmişlerdir. Örneğin Yedikule'de kahvecilik yapan Hacı Stefan adlı kişinin kahvehanesine 7 Kasım 1908'de polis baskını yapılmış ve kahvehanede kumar oynandığı tespit edilerek kahvehane kapatılmıştır. Bunun üzerine Stefan, Polis Müdüriyetine değişik tarihlerde üç dilekçeyle başvurarak haksızlığa uğradığını, başka kahvehanelerde alenen kumar oynatıldığı halde kendi kahvehanesinde kumar bulunmaması nedeniyle kahvehanesinin zarara uğratılmak istendiğini öne sürmüştür. Ayrıca 27 senedir kahvecilik yaptığını, bu müddet zarfinda hiçbir kötü halinin bulunmadığını, müşterilerinin büyük bir kısmının itibarlı kimselerden oluştuğunu, Komiser Muavini Hayri Bey’in kahvehanede oynanan bilardoyu kumar olarak değerlendirdiğini, bilardo edevatını toplattırarak kanuni işlem başlattığını, yapılan bu işlemin haksız olduğunu belirtmiştir. ${ }^{30}$ Bunun üzerine Dersaadet Polis Müdüriyeti, Samatya Polis Merkezi'ne durumu bildirmiştir. Samatya Polis Merkezi tarafindan gönderilen cevabî yazıda, Hacı Stefan'ın bir kumarbaz olduğunun merkezce sabit olduğu, kahvehanede, aynı mahallede sakin Sarraf Yorgi Efendi, Hacı Menoli'nin dükkanında çalışan Vasili, Kuyumcu Haranet ve Vladogop adlı kişilerin "bakara" adlı bir kumar oynarken suçüstü yakalandıkları, kumar alet ve edevatıyla birlikte müdde-i umumiyeye gönderildikleri bildirilmiştir. Yazıda "bakara" adlı oyunun kumardan sayıldığı, Komiser Muavini Hayri Bey’in haksız bir muamele yapmadığı, vazifesine dört elle sarılmış, namusunu muhafaza eden bir memur olduğu, kumarbazların bu gibi memurlar hakkında yanlış beyanlarda bulundukları, dolayısıyla şikâyetin dikkate alınmaması gerektiği ifade edilmiştir. ${ }^{31}$

Kahvehanelerde kumar alışkanlığına dair şikâyetler sadece İstanbul'a has bir durum değildi. Taşrada da kumarın yaygınlaştığına dair şikayetler alınmıştır. Örneğin Sadaret makamına gelen bir ihbarda Adana'da Rum Kahvehanesi adında bir kulüpte kumar oynatıldığı, kahvehanede Osmanlı topraklarına sokulması yasak olan muzır neşriyat bulunduğu, ${ }^{32}$ Ermeni ve Rum ahalinin bunları okuyarak bilgi

30 BOA, Dahiliye Emniyet-i Umûmiye Tahrirat Kalemi Evrakı (DH.EUM.THR.), nr. 14/50, s. 002, Tarih: 7 Teşrinisani 1325/20 Kasım 1909.

31 BOA, DH.EUM.THR., nr. 14/50, s. 001, Tarih: 11 Teşrinisani 1325/24 Kasım 1909.

32 XVIII. yüzyılın başından itibaren Osmanlı Devleti’nde posta işletmelerine yabancılar el atmaya başlamışlardı. Önceleri diplomatik amaçlarla çalışmaya başlayan yabancı posta örgütleri zamanla kendi postanelerini de kurmuşlardı. XVIII. yüzyılın ikinci yarısına kadar yabancı devletler kendi posta sistemini ve postanelerini oluşturmuştu. Osmanlı Devletinde 1840'da posta hizmetlerinin örgütlenmesi sonrasında yabancı posta teşkilatlarının kaldırılması gündeme gelmiş ancak bir sonuca ulaşılamamıştı. Sultan II. Abdülhamid döneminde zararlı neşriyatın ülkeye girmesini 
edindikleri, Aristidi Bıcıoğlu adlı bir kişi tarafindan Yunan Milli Piyangosu ${ }^{33}$ biletleri satıldığı haber verilmiştir. İhbarda, kahvehanenin daha evvel de teftiş edildiği, ancak teftiş eden vilayet tercümanı Avadis Efendi’nin rüşvet aldığg belirtilmiştir. Sadaret makamı bu ihbarı Dahiliye Nezareti'ne bildirmiş ve gerekli incelemenin yapılmasını istemiştir. Dahiliye Nezareti, Adana vilayetine durumu bildirerek ivedilikle inceleme başlatılmasını talep etmiştir. Adana vilayeti tarafindan yapılan incelemede ihbarın asılsız ve uydurma olduğu ortaya çıkmıştır. Zira anılan kulüpte sadece yılbaşı gecesinde Fransızlar tarafindan oyun oynandığı diğer zamanlarda ise kesinlikle oyuna müsaade edilmediği vilayetçe bildirilmiştir. Kulüp hakkındaki diğer şikâyetlerin de asılsız olduğu anlaşılmıştır. ${ }^{34}$

Öyle görünüyor ki Osmanlı toplumda kumar alışkanlığının en önemli mekanları kahvehaneler olmuştur. Hükümet kamu ahlakını korumak ve kumarı kısıtlamak için ahalinin şikayetlerini dikkate almış ve kahvehanelere baskın düzenlemiştir. Böylece dinen ve hukuken yasak olan kumarın halka açık mekanlarda yayılması engellenmeye çalışılmıştır.

\section{Kumar Oynanan Diğer Umumî Mekânlar}

XIX. yüzyıl gündelik yaşamında kahvehanelerin yanında kulüpler de dikkat çekici mekânlar arasındadır. Batılı yaşam tarzının İstanbul'a getirmiş olduğu kulüpler kumarın yaygın olarak oynandığı yerler arasındadır. Geleneksel eğlence mekânlarından olan kahvehaneler daha çok halka hitap ederken, kulüpler ise daha ziyade üst düzey devlet memurlarının, Levantenlerin ve yabancı misyonların devam ettiği sosyal alanlar olmuştur. ${ }^{35}$

Hükümet, kahvehanelerde olduğu gibi kumar oynanan kulüplere de baskın yaparak kumarı engellemeye çalışmıştır. Ancak bu baskınların caydırıcılığının sınırlı

engellemek için yabancı postaneler kaldırılmaya çalışılmış ancak bu mümkün olmayınca bazı tedbirler alınmıştır. Ayrıntılı bilgi için bk. Yurda Güven Bezaz, Geçmişten Günümüze Haberleşme ve PTT Tarihi, Türkiye Haber-İş Sendikası Yay., Ankara (2007?) s. 101-109; Tanju Demir, "Salih Zeki ve Ecnebi Postaneleri’nin Kaldırılması Konusundaki Görüşleri”, Osmanlı Bilim Araştırmalar, C VII/1, (2005), s. 170-172.

33 XIX. yüzyılın sonlarından itibaren yabancı postaneler aracılığıyla başka ülkelerden Osmanlı ülkesine getirilerek satılan piyangolar bulunmakta idi. Bu sorun teşkil ettiği için 1887'de yasaklanmıştı. Mete Tunçay, Türkiye'de Piyango Tarihi ve Milli Piyango İdaresi, Milli Piyango İdaresi Yay., Ankara 1993, s. 75-76.

34 BOA, Dahiliye Nezareti Mektubî Kalemi (DH.MKT.), nr. 1237/19, s. 01, 01, 02, 02, 03, 02, Tarih: 4 Mart 1324/ 17 Mart 1908.

35 Yolal, agt., s. 81. 
olduğu anlaşılmaktadır. Zira baskın yapılan kulüplerde kumar oynanmaya devam edilmiştir. Örneğin Emniyet-i Umûmiye Müdüriyeti tarafindan Beyoğlu Polis Müdüriyetine gönderilen 26 Kasım 1910 tarihli bir yazıda Beyoğlu'nda Yunan Konsolosluğu civarında bulunan Osmanlı İtilaf Kulübünde kumar oynanmakta olduğu haber verilmiş ve bunun doğru olup olmadığının araştırılması istenmiştir. Emniyet-i Umûmiye Müdüriyeti Birinci Şubesinden gönderilen cevabî yazıda, yapılan inceleme sonucunda elde edilen bilgiler paylaşılmıştır. Buna göre daha evvel de anılan kulüpte kumar oynandığına ilişkin bir şikâyet alınmış, mekâna bir polis baskını düzenlenerek kumar oynandığı tespit edilmiş̧ir. Son şikayet üzerine buraya yeniden baskın düzenlenmiş, kulüpte kumar oynandığı bir kez daha görülmüştür. ${ }^{36}$

Sadece İstanbul'da değil Osmanlı'nın diğer şehirlerinde bulunan kulüplerde de kumar oynandığı anlaşılmaktadır. Örneğin Aydın vilayetine gönderilen 28 Mart 1906 tarihli tezkereye göre, İzmir'de Alyoti mevkiinde Nikola İstavridis adlı bir kişi resmi müsaade almadan bir avcılar kulübü açmıştır. Kumar oynanan bu mekâna hükümet memurları ve yabancı tebaadan çok sayıda kişi de devam etmiştir. Kumar esnasında büyük meblağlar ortaya konulmuş ve memurlar gafil avlanmıştır. Söz konusu belgeden anlaşıldığı üzere bu durum daha evvel Aydın vilayetine şikayet edilmiş ancak hiçbir işlem yapılmamıştır. Bu sefer şikayetçi olan kişi mektubunu Fransızca kaleme alarak merkeze göndermiştir. Sadâret, mektubu Fransızcadan tercüme ettirerek Aydın vilayetine havale etmiştir. Ayrıca anılan kulübün resmi açılış belgesi bulunup bulunmadığının ve burada kumar oynandığı hususunda alınan ihbarın doğru olup olmadığının araştırılması ve gerekli olan tahkikatın yapılması talep edilmiştir. ${ }^{37}$

Kumar sadece kahvehanelerde ve kulüplerde yaygin değildi. Özellikle halkın kullanımına açık bazı yerlerde de kumar oynandığına dair çok sayıda şikâyet gelmiştir. Mesela İstanbul'un sayfiye yerlerinden birisi olan ve II. Abdülhamid döneminde önem kazanan Yalova kaplıcaları bu umumi mekânlardan birisidir. Kaplıca hamamları ile ilgili ayrıntılı bir çalışmaya rastlanmamakla birlikte kaplıcaların II. Abdülhamid'in cülusunun 25. yl dönümü münasebetiyle tamir ve ihya edildiği, ayrıca buraya yeni hamam ve otel inşa edildiği bilinmektedir. Bu dönemde ayrıca İstanbul-Yalova iskelesi arasında düzenli vapur seferleri de başlamıştı. ${ }^{38}$ II.

36 BOA, DH.EUM.KADL., nr. 2/2, 001-003, Tarih: 13 Teşrinisani 1326/26 Kasım 1910.

37 BOA, BEO, nr. 2795/209563, s. 01, 01, Tarih: 15 Mart 1322/28 Mart 1906.

38 Metin Tuncel, "Yalova", İslam Ansiklopedisi, G 43, Türkiye Diyanet Vakfi Yay,. İstanbul 2013, s. 
Abdülhamid döneminde önemli hale gelen Yalova kaplıcaları esasen 1909 yılına kadar Maliye Nezareti tarafindan işletilmiştir. Bilahare bu uygulama değiştirilerek kaplıcalar müzayede yöntemiyle şirketlere kiralanmaya başlamıştır. Bu müzayedelerde kumarın kati olarak yasak olduğu müzayede komisyonu tarafindan ilgililere belirtilmiştir. Yalova kaplıcaları 1909'da Reşid Bey ve ortakları olan Bahayas ve Konstantin adlı kişilere ait Hamamlar Şirketi'ne ihale edilmiştir. ${ }^{39}$

Kaplıcaların işletmesinin şirketlere bırakılmasının ardından kaplıcalarda kumar oynatıldığına dair şikâyetler artmıştır. Bu meyanda Yalova kaplıcalarını işleten kişilerin burada kumar oynattıklarına dair Maliye Nezareti’ne gelen bilgi üzerine Maliye ve Dâhiliye Nezaretleri harekete geçmiştir. ${ }^{40}$ Şikayet dilekçelerinde yer alan bilgilere göre kaplıcalar kumarhaneye çevrilmiş olup kanuna aykırı olarak kumar oynatılmıştır. Hatta kaplıcaya kadınlar getirtilerek, "bakara" ve "pati şovu" gibi oyunlar sergilenerek ahali soyulmuştur. Maliye Nezareti tarafindan kumara müsaade edilmeyeceği ısrarla tekrarlanmasına rağmen işletme hakkında gerekli hukuki düzenlemenin yapılmaması yeni şikâyetlere neden olmuştur. Mesela Yalova kaplıcalarını kiralamak için ihaleye giren Galata esnafindan Cevan Şalcı bu hususta bir dilekçe yazarak, Yalova kaplıcaları gazinosunda bir kumarhane açıldığını, burada "rulet, bakara" gibi oyunlar oynatıldı̆̆ını, birçok kişinin soyulduğunu, bu durumun herkes tarafindan bilindiğini, kiralayanlarla ilgili gerekli işlemlerin başlatılmamasının hayret verici olduğunu dile getirmiştir. Cevan Şalcı, ayrıca hükümetin kumar oynatmaları nedeniyle sözleşmeyi feshetme hakkının olduğunu hatırlatmış, şikayetinin dikkate alınmasını istemiştir. ${ }^{41}$

Maliye Nezareti dilekçeyi inceleyerek kaplıcalarda kumar oynandığına ilişkin soruşturmanın yerel yönetim tarafindan başlatılacağını bildirmiştir. ${ }^{42}$ Yalova Kaymakamı ve İzmit Mutasarrıflı̆ğndan gönderilen yazıda, Maliye Nezareti ve söz konusu şirket arasında imzalanan mukavelenâmenin 7. maddesinde kaplıcalarda şirket için hususi bir kulüp açılmasına müsaade edildiği, ayrıca mevsimin bitmesi nedeniyle hamamların tatil edilmiş olmasından dolayı gelecek yıl itibarıyla Maliye

307.

39 BOA, DH.ID., nr. 68/15, s. 002,001, 006, 001, Tarih: 5 Eylül 1327/18 Eylül 1911, 28 Eylül 1327/11 Ekim 1911.

40 BOA, DH.İ., nr. 68/15, s. 01,01, Tarih: 8 Kanunuevvel 1327/21 Aralık 1911.

41 BOA, DH.ID., nr. 68/15, s. 002,001, 006, 001, Tarih: 5 Eylül 1327/18 Eylül 1911, 28 Eylül 1327/11 Ekim 1911.

42 BOA, DH.ID., nr. 68/15, s. 003,001, 004, 001, Tarih: 27 Eylül 1327/ 10 Ekim 1911. 
Nezareti'nden verilecek irade ile gereğinin yapılacağı bildirilmiştir. ${ }^{43}$ Dahiliye Nezareti ve Maliye Nezareti bu duruma itiraz etmiştir. Taraflar arasında imzalanan mukavelenâmenin 7. maddesinde şirket için özel bir kulüp tesisine izin verilmiş olsa dahi şirketin Osmanlı kanunlarına ve nizamlarına tabi olduğuna dair esasların da mukavelenâmenin 13. maddesinde belirtildiği, dolayısıyla kumar yasağına şirketin uyması gerektiği hatırlatılmıştır. ${ }^{44}$

Zaman içerisinde Yalova hamamlarında kumar oynatılması ile ilgili şikâyetler artmıştır. Maliye Nezareti'ne Paris'ten gönderilen Fransızca ve imzasız bir ihbar mektubunda Yalova hamamların işleten kişilerin ahlaksız oldukları, şirketin çalışmak için kaplıcalara yerleştirdiği kişilerin Avrupa'da isim yapmış, sabıkalı kumarcılar olduğu, bu kişilerin Yalova'da kalmaları halinde burada kumarın daha da artacağı bildirilmiştir. ${ }^{45}$ Bunun üzerine Dahiliye Nezareti tarafından İzmit Mutasarrıflı̆̆ına gönderilen yazıda, Yalova kaplıcaları işletme sahiplerinin özel gazinoda kumar oynatmakta oldukları, kumarda tecrübeli kişileri burada çalıştırdıkları, kadınlar vasıtasıyla insanları sefâhate sürükledikleri, bu durumun civar köyler ve kaplıcaya gelen namuslu aileler üzerinde kötü tesir yaptığı belirtilerek gerekenin yapılması istenmiştir. ${ }^{46}$

Dahiliye Nezareti'ne Göztepe Kalındağ Caddesinde sakin olan Süleyman adlı bir kişi tarafindan yazılan diğer bir ihbar mektubunda da benzer ifadeler yer almaktadır. Mektupta, Yalova kaplıcaları imtiyaz sahibi Reşid Bey ve arkadaşlarının kaplıca içerisinde "hususi gazino" adlı binada kumar oynattıkları, özel olarak çalıştırdıkları kumarbazlarla insanlardan para çarptıkları, ayrıca kadınlar vasıtasıyla buraya gelen kişileri sefâhate sürükleyip her türlü rezaleti yaşattıkları, bu durumun köylüler ve kaplıcaya gelenler için olumsuz bir örnek oluşturduğu bildirilmiştir. Fransa'da dahi kumarhaneler kapatılmış iken kanunen yasak olan Osmanlı toprağında alenen kumar oynatılmasının halk nazarında hükümetin kumara müsaade etmekte olduğu izlenimi verdiği, kumarın birçok aile ve hanelerin sönmesine ve yönetimin zarar görmesine sebep olduğu, bu konuya dikkat edilmesi gerektĭgi belirtilmiştir. Dahiliye Nezareti şikayet mektubunu Maliye Nezareti'ne ve İzmit Mutasarrıflı̆̆ına göndermiştir. ${ }^{47}$

Belleten, Aralık 2020, Cilt: 84/Sayı: 301; 1143-1174

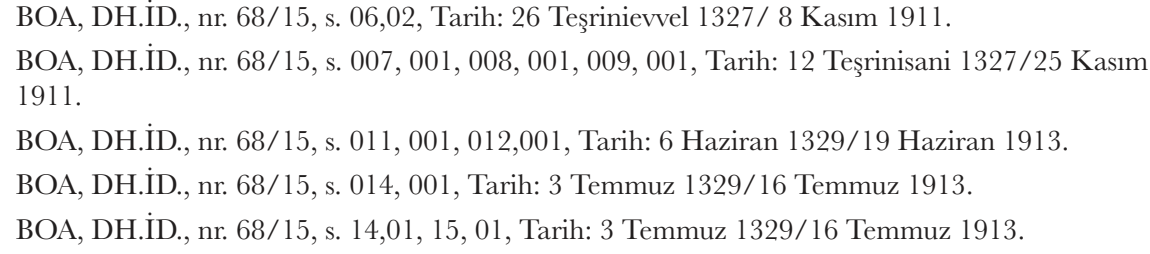


İzmit Mutasarrıfı gönderilen ihbarı değerlendirmiş ve gerekli incelemeyi başlatmıştır. İnceleme sonunda Yalova kaplıcalarındaki durumun şikâyet mektuplarında bahsedildiği gibi olmadığı ortaya çıkmıştır. Mutasarrıf tarafından Dâhiliye Nezareti'ne gönderilen tezkerede, sadece kulüp denilen hususi bir mahalde bazı ekâbir tarafindan bakara ve rulet oynandığ hatta buna bizzat kendisinin de şahit olduğu belirtilmiştir. Mutasarrıfa göre kulüp, Avrupa'daki örneklerine benzer şekilde kaplıcalarda bulunması gereken bir bölümdür. Burada oynanan oyunlar sadece eğlence amaçlıdır. Kulüpte şikâyet mektuplarında ifade edilen durumlar yaşanmamaktadır. İzmit Mutasarrıfi, müşterileri sefâhate teşvik eden kadınlar hususunda ise şunları ifade etmiştir; hamamlarda geceleri kişilerin istirahat ve eğlencelerini temin etmek için Dersaadet'ten ve Avrupa'dan gelen üç-dört zanaatkâr bulunmaktadır. Bu kişiler hamamda çalışan ahlaklı insanlardır ve dolayısıyla insanları sefâhate sevk etmek gibi durumları da bulunmamaktadır. ${ }^{48}$

Kumar, kahvehane, kulüp gibi mekanlar dışında sokaklarda da oynanmıştır. Özellikle okulların bulunduğu bölgelerde sokakta oynanabilen kumar ve şans oyunları yaygınlaşmıştır. Öğrenciler okul çıkışlarında kumarbazların bulunduğu köşeye gelerek şanslarını deneyerek kumara müptela olmuşlardır. Bu nedenle okul müdürleri, öğrencileri kumara alışabilecekleri ortamlardan uzak tutmaya çalışmıslardır. Maarif Nezareti'nin bunun için özel bir çaba sarf ettiğini söylemek mümkündür. Özellikle İstanbul'da kumarın birçok alanda ve mekânda yaygın ve aleni olarak oynandığı düşünülürse, öğrencileri kumardan ve kumarcılardan uzak tutmak okul idarelerinin en önemli görevleri arasında olmuştur. Zira kumarcılar okulların bulunduğu alanlara giderek, öğrencilere çeşitli şans oyunları oynatmışlardır. Maarif-i Umumiye Nezareti okulların bulunduğu civarda öğrencileri ahlaksızlığa ve kumara alıştırmak isteyen kişiler hakkında işlem başlatmıştır. Örneğin 29 Ocak 1906 tarihli olup Maarif-i Umumiye Nezareti'nden Zaptiye Nezareti'ne gönderilen bir belge buna örnek gösterilebilir. Belgeye göre; Şehzade Camii havalisinde Kumarbaz Ali adlı bir kişi bu civarda bulunan mektep talebelerine beşer kuruş kazanacaklarını vaat ederek ceviz oynatmakta ve ayrıca nişan aldırmaktadır. Özellikle Vefa Mekteb-i İdadisi ile civarda bulunan diğer mektep öğrencileri burada toplanmaktadır. Hatta bir Cumartesi akşamı Beyazıt Rüsstiye Mektebi talebeleriyle Şems'ül Maarif ve Hamidiye Mektebi öğrencileri anılan camii bölgesinde toplanarak burada nişan tatbiki yapmışlardır. Mektep müdürleri talebelerin bu bölgede

48 BOA, DH.ID., nr. 68/15, s. 16, 01, 18, 01, Tarih: 17 Temmuz 1329/30 Temmuz 1913, 4 Eylül 1329/17 Eylül 1913. 
toplanmasını engellemek için civarda görevli olan polislere uyarıda bulunmuştur. Ancak belgede ifade edildiğine göre bu şikâyete itibar edilmemiştir. Maarif-i Umumiye Nezareti, Zaptiye Nezareti'ne bir yazı yazarak, Kumarcı Ali ve onun gibi şahısların mektep talebelerinin bulunduğu bölgelerden uzak tutulmasını, talebelerle görüşmesinin engellenmesi için bölgeye zabıta gönderilmesini ve zabitaların bu bölgeleri takip altına almasını talep etmiştir. ${ }^{49}$

\section{Hususî Hanelerde Kumar}

Kahvehane, kulüp ve diğer umumi mekânların sık sık kontrol edilmesi kumarın hususi hanelerde de oynanmasina neden olmuştur. Kumar müptelaları bir araya gelerek evlerde, apartmanlarda özel toplantılar yaparak kumar partileri düzenlemişlerdir. Bu tür kumar toplantılarının ortaya çıkarılması kumarcıların yakınları, mahalle veya apartman sakinlerinin şikâyetleriyle olmuştur. Dahiliye Nezareti özel hanelere yapılan kumar baskınları sırasında yaşanan suiistimalleri önlemek ve gerekli tedbirleri almak için meseleyi Meclis-i Mahsûs-1 Vükelâ'ya havale etmiştir. Bu husus 2 Ağustos 1905 tarihli Meclis-i Mahsûs-1 Vükelâ'da görüşülmüştür. Müzakere sırasında bazı kimselerin kumar oyunlarını vesile ederek evlerde toplantılar yapmasının önüne geçilmesi için Zaptiye Nezareti’nin toplantı düzenlenen evleri tespit ederek buralarda gerekli tedbirleri alması kararlaştırılmıştır. ${ }^{50}$ Öte yandan Meşrutiyet'in ilanıyla evlerde kumarın arttığına dair şikâyetler artmıştır. Zira Kânûn-1 Esâsî'de yer alan "mesken dokunulmazlığı" hükmü gereğince hane sahibinin izni olmaksızın evlere girilmesi yasaklanmıştır. Bu esasa bağlı olarak kolluk kuvvetleri kumar şüphesiyle evlere baskın yapmakta tereddüt etmiştir. ${ }^{51}$

Özellikle Beyoğlu civarındaki evlerde kumar oldukça yaygın hale gelmiştir. Sadrazamlık bu konuda Dahiliye Nezareti’ni uyarmıştır. Örneğin 5 Kasım 1904'te Sadrazamlıktan Dahiliye Nezareti'ne gönderilen yazıda, Osmanlı memleketlerinde kumarın yasak olduğunun nizamnâme ile bildirildiği, zabitalarca bu hususta gerekli tedbirler alınmasına rağmen son zamanlarda Beyoğlu’nda bazı özel hanelerde kumar oynandığının haber alındığı ifade edilmiştir. Sadrazamlık, kumar oyununun şiddetle men edilmesi, kumar bahanesiyle toplantılar yapılmasına ke-

49 BOA, Maarif Mektubi Kalemi (MF.MKT.), nr. 909/33, s. 01-02/02,01/03,02, Tarih: 16 Kanunusani 1321/29 Ocak 1906.

50 BOA, Yıldız Resmi Maruzat (Y.A.RES.), nr. 132/003, s. 01, 01/02,01, Tarih: 20 Temmuz 1321/2 Ağustos 1905.

51 BOA, Y.A.RES., nr. 132/003, s. 01, 01/02,01, Tarih: 20 Temmuz 1321/2 Ağustos 1905; Düstur, Cûz-i Rabi, Maarif Nezaret-i Celilesinin Ruhsatıyla, Matbaayı Amire, İstanbul 1295, s. 7-8. 
sinlikle meydan verilmemesi ve bununla ilgili gerekli tedbirlerin alınması için Zaptiye Nezareti'ne durumun tebliğ edilmesini istemiştir. ${ }^{52}$

Bu dönemde Dahiliye Nezareti'ne ulaşan ihbarlarda devlet memurların evlerinde kumar partileri düzenlediklerine dair şikayetler de söz konusudur. Örneğin Hamidiye Hafif Süvari Alayları Kumandanı Mirliva Ahmed Paşa tarafindan Yıldız Sarayı Başkitabet Dairesine gönderilen 10 Mayıs 1908 tarihli şifrede, Edirne'de Vilayet İdare Meclisi Başkatibi Reşid Bey ile Belediye Reisi Dilaver Bey'in evlerini bir kumarhane gibi kullandıkları ve bazı kişileri gece evlerine toplayarak geç saatlere kadar kumar oynayıp, ortada yüzlerce lira döndürdükleri, bu durumdan valinin de haberdar olduğunu bildirmiştir. ${ }^{53}$ Genel olarak memurların kumara müptela olmalarının en temel nedeni geçim sıkıntısı olmalıdır. Bunun yanında memurların alım gücünü yitirmesi, maaş ödemelerinde yaşanan sıkıntılar, yaşam tarzı değişiklikleri etkili olmuştur.

Kumarhanelere uygulanan sıkı tedbirler zaman zaman diplomatik sıkıntılara sebep olmuştur. Örneğin 1910 yılının sonu ve 191 l'in başlarında Beyrut'ta kumara karşı sıkı tedbirler uygulanırken İtalyan tebaasından olup Beyrut'ta ikamet eden Vinçenzo Çantaro adlı bir şahsın hanesinde kumar oynattığına dair alınan ihbar üzerine eve baskın düzenlenmiştir. İtalyan Konsolosluğu'na haber verilmeksizin Italyan vatandaşlarına ait meskenlere takibat yapılması, eşya ve mallarına el konulması devletler arasında gerginliğe sebep olmuştur. Çantaro, kendisine yapılan bu muameleyi protesto etmiş, bunun üzerine zabıta tarafindan tehdit edilmiştir. İtalyan vatandaşına yapılan muamele nedeniyle Beyrut İtalyan Konsolosu da durumu protesto etmiştir. Ancak olay bununla kalmamış, İtalyan Konsolosluğu'nun protestosunun ardından Beyrut valisi konsolosa tahkikat yapılacağı bilgisini iletilmesinden hemen sonra Çantaro'nun hanesine bir kez daha girilmiştir. Hariciye Nezareti durumu etraflıca öğrenmek için Dahiliye Nezareti’ne başvurmuş ve İtalyan Sefareti’nin protestosuna neden olan bu olay hakkında ayrıntılı bilgi istenmiştir. Anlaşılan o ki Hariciye Nezareti, bu uygulamadan rahatsızdır. 5 Mart 1911 tarihinde Hariciye Nazırı adına Müsteşar tarafından Dâhiliye Nezareti’ne gönderilen yazıyla bu rahatsızlık dile getirilmiştir. Buna göre Beyrut'ta kumara karşı gerekli tedbirler alınırken kanuni esaslar çerçevesinde hareket edilmesi, bu

52 BOA, BEO, nr. 2443/183160, s. 01,01, Tarih: 23 Teşrinievvel 1320/ 5 Kasım 1904; BOA, DH.MKT., nr. 908/83, s. 001, 001, 002, 002, Tarih: 23 Teşrinievvel 1320/9 Kasım 1904.

53 BOA, Yıldız Perakende Evrakı Askeri Maruzat (Y.PRK.ASK.), nr. 256/50, s. 01,01/02,01, Tarih: 27 Nisan 1324/10 Mayıs 1908. 
kapsamda İtalyan tebaası ikametgâhlarına girilirken konsolosluğa haber verilmesinin uygun olacağı belirtilmiştir. ${ }^{54}$ Dahiliye Nezareti ise Osmanlı Devleti topraklarında kumarın ve kumarhanelerin yasak olmasından dolayı konsolosluklarla sorun yaşanmaması için belirli usul ve esaslar çerçevesinde İtalyan tebaası hanelerine girilebileceğinin konsolosluklara ve İtalyan Sefareti'ne bildirilmesini istemiştir. ${ }^{55}$

Dahiliye Nezareti tarafindan 8 Mart 191 l'de Beyrut vilayetine gönderilen tezkerede konu hakkında ayrıntılı bir inceleme istenmiştir. ${ }^{56}$ Yapılan tahkikatın sonucu Vinçenzo Çantaro adlı kişinin ikametgahı olarak ifade edilen yerin Osmanlı tebaasından bir kişi tarafindan kiralandığı anlaşılmıştır. Hanenin kapısının açık olduğu sırada bir jandarma müfrezesi haneye girmiştir. Esasen bu bölge polis kontrolü altında olduğu için jandarmanın müdahale etmesi yersiz olmuştur. Jandarma kumandanlığına bu hususla ilgili ihtarda bulunulmuştur. Haneye giren zabit yakalanmış ve hakkında gerekli işlem başlatılmıştır. ${ }^{57}$

Hariciye Nezareti ile Dahiliye Nezareti arasında Vinçenzo Çantaro ile ilgili yazışmalar 6 Haziran 1911'e kadar devam etmiştir. Dahiliye Nezareti, Çantaro'ya yapılan muamelenin gerekçelerini ortaya koymaya çalışmışır. Bu noktada Çantaro'nun ikametgâhının aslında Osmanlı tebaasından bir kişiye ait olduğu ve yine Osmanlı tebaasından birisinin kiraladığı, ancak bilahare 20 Mayıs 1910'da hanenin İtalyan tebaasından birisine devredilmiş olduğu, fakat bununla ilgili bir kontratın yapılmadığı ortaya çıkmıştır. Ancak Hariciye Nezareti bu açıklamayı kabul etmemiştir. İtalyan tebaasından bir kişi ve ailesinin gece ve gündüz ikamet eylediği herkesçe bilinen bir yerin İtalyan ikametgâhı olarak kabul edileceği, bununla ilgili yapılan diğer açıklamaların gerçekçi olmadığı dile getirilmiştir. ${ }^{58}$

\section{Ramazan Aylarında Kumarla Mücadele}

Ramazan aylarında kumar ve içki hususunda daha titiz davranıldığı görülmektedir. Sadrazamlık makamından Dahiliye Nezareti'ne yazılan tezkerelerde özellikle ramazan aylarında Müslümanların adabına, İslam kadınlarının tesettür kaideMart 1911. ran 1327/19 Haziran 1911.

BOA, Dahiliye Nezareti Hukuk Evrakı (DH.H.), nr. 22/003, s. 002,001, Tarih: 20 Şubat 1326/5

BOA, DH.H., nr. 22/03, s. 001,001, Tarih: 23 Şubat 1326/8 Mart 1911.

BOA, DH.H., nr. 22/03, s. 001,001, Tarih: 23 Şubat 1326/8 Mart 1911.

BOA, DH.H., nr. 22/003, s. 003-001, 004, 001, Tarih: 6 Mart 1327/19 Mart 1911.

BOA, DH.H., nr. 22/003, s. 005,006, 007, 008, Tarih: 20-24 Nisan 1327/7 Mayıs 1911, 6 Hazi- 
lerine itina ve dikkat etmesi, ayrıca kumar oyunları gibi şer’i olarak yasak olan oyunların oynanmaması, bu amaç için toplanılmasının yasaklanması, ayrıca bu yasaklara dair bütün gazetelere ilan verilmesi istenmiştir. ${ }^{59} \mathrm{Bu}$ hususta Dahiliye Nezareti harekete geçmiş, Sadâretin uyarıları doğrultusunda gerekli tedbirlerin alınması amacıyla Zaptiye Nezareti'ne bir tezkere göndermiştir. Söz konusu tezkerede uyarılar tekrarlandıktan sonra zabitanın bu konuda titizlikle hareket etmesi, Beyazıt Meydanı ve Direklerarası gibi yerlerde kadınların adaba uygun olmayan şekilde gezmelerinin önlenmesi, zabıta tarafindan yasaklara aykırı hareket edenler hakkında gerekli işlemin yapılması ve Zabıta Nizamnâmesinin tatbik edilmesi istenmiştir. ${ }^{60}$

Ramazan aylarında kumar oynandığı bildirilen bazı gazino ve kıraathanelerin kapatılması da söz konusu olmuştur. Örneğin 12 Kasım 1904 tarihli olup Yıldız Sarayı Başkitabet Dairesinden Zaptiye Nezareti'ne gönderilen tezkerede Aksaray’da Mustafa Efendi’nin, Direklerarası'nda Ali Çavuş’un gazinolarının üst katında ve yine Direklerarası'nda Erzurum Kıraathanesi ile Fozya Kıraathanesinin arka bölümlerinde bulunan kulüp adlı mahallerde kumar oynandığı bildirilmiştir. Belgede kumarın şer'an ve kanunen yasak olduğu, hatta bu konuda henüz yeni sayılacak bir padişah iradesinin bulunduğu hatırlatılmış ve Zaptiye Nezareti’nin gerekli tedbirleri almaması eleştirilmiştir. Zira belgede bir hatırlatma daha yapılarak daha önce Dahiliye Nezareti tarafindan Zaptiye Nezareti'ne gönderilen bir tezkerede zabitanın kumar oynanmasına müsamaha gösterdiğine dair yapılan bir eleştiri hatırlatılmıştır. Bu noktada zabıtaların mesuliyetlerinin gereğini yapmaları, adı geçen mahallerde bulunan kumarhanelerin kapatılması istenmiştir. ${ }^{61}$

Ramazan aylarında kumar yasağıyla ilgili hatırlatmalar ilerleyen yıllarda da yinelenmiştir. Örneğin 14 Ekim 1907 tarihli olup Sadrazamlık Mektubi Kaleminden Zaptiye Nezareti'ne gönderilen tezkerede kumar oyununun yasaklanması ve bununla ilgili alınması gereken tedbirler üzerinde durulmuştur. Belgeye göre, Makriköy istasyonu civarında bulunan gazinoda her gece sahura kadar kumar oynanmaktadır. Hatta gündüzleri oraya devam eden İslam ahalisi tarafindan bu durum alenen görülmüştür. Yazıya göre, zabıta memurları kumar oynanmasına s. 005, 001, Tarih: 26 Teşrinievvel 1320/8 Kasım 1904.

61 BOA, Y.PRK.BŞK., nr. 73/64, s. 01,01, Tarih: 4 Ramazan 1322/12 Kasım 1904. 
müsamaha göstermektedir. Sadâret, bu durumdan oldukça rahatsılık duymuş, şer'an ve kanunen yasak olan kumarın mübarek ramazan ayında yasaklanmasına bir kat daha itina gösterilmesini, İslam dininin haram kıldı̆̆ı kumarın men edilmesi için gerekli tedbirlerin alınmasını emretmiştir. Sadâret ayrıca kumara müsamaha gösteren memurlar hakkında inceleme başlatılarak gerekli cezanın verilmesini istemiştir. $^{62}$ Zaptiye Nezareti meseleyi ivedilikle incelemiş, Küçükçekmece Kaymakamlığından konuyla ilgili tahkikat yapmasını talep etmiştir. İnceleme sonucunda elde edilen bilgiler 2 Kasım 1907'de Zaptiye Nezareti tarafindan Sadârete gönderilmiştir. Buna göre Makriköy’de istasyon civarında Osmanlı tebaasından Miço ve Koçu adlı kişiler tarafindan kiralanan gazinoda kumar oynanmadığı bildirilmiştir. ${ }^{63}$

Osmanlı makamları tarafindan yapılan hatırlatmalara ve alınan tedbirlere rağmen ramazan aylarında kumarla ilgili şikâyetlerin sonu gelmemiştir. Örneğin 26 Ağustos 1910'da Emniyet-i Umûmiye Müdüriyetine gönderilen isimsiz bir ihbar mektubunda, kişi öncelikle böyle bir ihbarı yapma arzusunda olmadığını ancak kumarcıların beş on kuruş kazanmak için ailelerini ve evlatlarını perişan etmeleri nedeniyle bu ihbarı yapmak durumunda kaldığını belirtmiştir. Mektup sahibi bu açıklamanın ardından ramazanda Beyazıt çevresinde Arnavut Abdul Ağga'nın kiraladığı Türkiye Kıraathanesinde gece vakti kumar oynandığını dile getirmiştir. Kumarın afet ve neticelerinin çok kötü olduğunu, bayramdan sonra da bu kişilerin kumar oynamaya devam edeceklerini, perişan olan aileler ve çocuklar için duruma müdahale edilmesi gerektiğini belirtmiştir. ${ }^{64}$

Sadâret makamının ramazan ayında yasaklı fillerle ilgili hassasiyeti ve halkın kumar oynayanlarla ilgili şikâyetleri doğrultusunda kahvehane ve gazinolara kumar baskınlarının sıklaştırıldığı anlaşılmıştır. Yapılan baskınlar İstanbul Polis Müdüriyeti tarafindan Emniyet-i Umûmiye Müdüriyetine bildirilmiştir. Örneğin ramazan ayının 21. gecesi Büyükada'da Ermeni cemaatinden Mesroy adlı bir kişinin gazinosunda kumar oynandığının haber alınması üzerine buraya bir baskın yapılmış, kumarbazlar tutuklanmış, masa üzerinde bulunan kumar aletleri ve üç adet gümüş mecidiye müsadere edilmiştir. Yine 22. gecede hileli piyango çektiren ku-

BOA, BEO, nr. 3168/237572, s. 01,01, Tarih: 7 Ramazan 1325/1 Teşrinievvel 1323/14 Ekim 1907.

63

BOA, BEO, nr. 3168/237572, s. 02,01, Tarih: 26 Ramazan 1325/20 Teşrinievvel 1323/2 Kasım 1907.

64 BOA, DH.EUM.THR., nr. 51/20, s. 001, Tarih: 13 Ağustos 1326/26 Ağustos 1910. 
marcılar tutuklanmış ve adliyeye sevk edilmişlerdir. ${ }^{65}$ Keza Parmaklıkçı Hüseyin adlı bir kahvecinin kahvehanesinde kumar oynattığının ihbar edilmesi üzerine kahvehaneye polis baskını yapılmıştır. Baskın sırasında kumarbazlar ellerinde paralarla yakalanmışlardır. İskambil kağıtları ve çeşitli kumar eşyalarına el konulmuştur. Bu sırada kahveci Hüseyin’in de kumar oynadığı görülmüş ve adliyeye sevk edilmiştir. ${ }^{66}$

Hristiyanlar için kutsal sayılan günlerde de yasak olan fiillerle ilgili uyarılar gönderilmiştir. Örneğin Dahiliye Nezareti Emniyet-i Umûmiye Müdüriyeti tarafindan yayınlanmak üzere gazetelere gönderilen 5 Ocak 1911 tarihli ilan buna örnek gösterilebilir. İlanda yılbaşı yortuları münasebetiyle kumar lubiyatı ve silah atışına müsaade edilmeyeceği, silah atışının yortularda da yasak olduğu, bununla ilgili yasağın bütün memurlara tebliğ edilmesi istenmiştir. Emniyet-i Umûmiye Müdüriyeti tarafından gazetelere gönderilen ilan yazısının başlığında kumar lubiyatı ifadesi bulunmaktadır. Ancak belgenin ilerleyen satırlarında bazı cümlelerin üzeri çizilerek ilan kısaltılmıştır. Silah atımı ve diğer yasaklı olan fillerin engellenmesi vurgusu yapılmıştır. Kumar da bu yasaklı eylemler arasındadır. ${ }^{67}$ Söz konusu ilan bir gün sonra gazete sütunlarına yansımıştır. Örneğin Tanin ve Sabah gazetelerinin 6 Ocak 1911 tarihli nüshasında ilan yayınlanmıştır. Tanin'de "Silah Atmak Yasaktır" başlı̆̆ıyla yer alan ilanda; "Emniyet-i Umûmiye Müdüriyetinden; mütekarrib olan ynlbaşı yortulan esnasında silah atmak gibi harekât-ı memnûada bulunmaktan tevâkki edilmesi ve bu bâbdaki memnûiyyet-i câriyenin muhafazasına itinâ edilmesi hakkında bilumum memurin-i zaptiyeye tebligât-ı cedîde îfâ olunduğu ilân olunur" denilmektedir. ${ }^{68}$ İlan Sabah gazetesinde de "Memnûiyet" başlığıyla verilmiş olup içerik olarak aynı şekilde yer almıştır. ${ }^{69}$

Ramazan aylarında kumar ve diğer eğlencelerin artışı Osmanlı basınında eleştiri konusu olmuştur. Örneğin Sebîlürreşâd'ın 12 Eylül 1912 tarihli nüshasında Halil Fahreddin'in "Bizde Ahlak" başlıklı yazısında ramazan aylarındaki eğlence düşkünlüğü şiddetle eleştirilmiştir. Yazıda bununla ilgili şu yorumlara yer verilmiştir:

“... ahlaksızlık bu kadarlıkla da kalmıyor ramazan-1 şerifde tâat ve ibâdâtla meşgul bulunması evâmir-i dinîyeden olduğu halde aksi emr olunmuş gibi

65 BOA, Dahiliye Emniyet-i Umûmiye Evrak Odası Kalemi Evrakı (DH.EUM.VRK.), nr. 04/12, s. 001, Tarih: Ramazan 1328/Eylül-Ekim 1910.

BOA, DH.EUM.VRK., nr. 20/30, s. 002, Tarih: 29 Eylül 1325/12 Ekim 1909. BOA, DH.EUM.KADL.,nr. 3/39, 01, Tarih: 23 Kanunuevvel 1326/ 5 Ocak 1911. "Silah Atmak Yasaktır", Tanin, Üçüncü Sene, No: 841, 24 Kanunuevvel 1326/6 Ocak 1911, s. 5. 
adî zamanlarda icra edilen ne kadar rezalet, ne kadar ahlaksılılk varsa hep bu mübarek ayda icra olunuyor. Muhadderât-1 İslamiyeye tecavüz envai lubiyata rağbet hep bu ayda revaç buluyor. Ramazan-1 şerifde namuslu bir kadının camiye gitmesi fevkalade müşkil bir hale geliyor. Bin dürlü hakarete düçar olmadan sokağa çıkmak hemen muhâl hükmüne giriyor. Bütün bunlar sûkut-u ahlakın birer timsali mücessemi değil midir? ... Geçen akşam bir arkadaşım ile beraber müşahid olduğumuz bir manzara cidden yürekleri sızlatacak bir mahiyeti haizdi. Çarşı boyunda yatsı ezan-1 şerif okunduğu halde tam karşısında bulunan kıraathane leb-â-leb dolmuş ve buna mukabil cami-i şerifde on iki kişiden başka kimse bulunmuyordu. Kıraathanede bulunan yüzlerce kişi kıraathanede oturmayı cami-i şerifte teravih namazı kılmaya tercih ediyorlardı". ${ }^{70}$

\section{Kadınların Kumara Tepkisi}

Kumarın yaygınlaşması en çok kadınları mağdur etmiştir. Kadınlar bununla ilgili şikâyetlerini Osmanlı makamlarına peyderpey iletmişlerdir. Bu hususta en çok şikâyet edenler Beyoğlu gibi İstanbul'un eğlence ile ön plana çıkan semtlerinde oturan kadınlardır. Bir kısım Beyoğlu kadını kumarın yaygınlaşmasından rahatsızlık duyduklarını dile getirmek amacıyla Emniyet-i Umûmiye Müdüriyetine "Beyoğlu Kumarzedegânı Kadınları" imzasıyla bir mektup göndermişlerdir. Bu mektupta, Beyoğlu'nda bulunan hususi hanelerde mesela Büyük Parmakkapi'da Ragip Paşa Apartmanında 17 nolu Madam Arslanyan'ın ikametgâhında kumar oynatıldığı, birçok namuslu ailelerin bu nedenle perişan oldukları bildirilmiştir. Bunun üzerine Emniyet-i Umûmiye Müdüriyeti tarafindan Beyoğlu Polis Müdüriyetine gönderilen yazıda "Beyoğlu Kumarzedegân Kadmnlarn" imzasıyla gönderilen mektubun içeriği bildirilmiş, Beyoğlu'nda bazı hususi hanelerde kumar oynatılmasına engel olunması istenmiştir. Emniyet Müdürlüğünün bildirdiğine göre, halkın kumarla ilgili hususlarda zabitanın göz yumduğuna yahut müsamaha gösterdiğine ilişkin yaygın bir kanaati bulunmaktadır. Bu nedenle Ragıp Paşa Apartmanındaki kumar ihbarının titizlikle incelenerek halkın bu yargısının silinmesi için gerekli tedbirler ivedilikle alınmalıdır. Polis Nizamnâmesinin 80. maddesinin polis memurlarına verdiği salahiyetler doğrultusunda kumar faaliyetine meydan verilmemelidir. ${ }^{71}$

Kadınlar bireysel olarak da şikâyetlerini dile getirmişlerdir. Eşi kumara alışmış 
olan kadınların mektupları adeta yalvarır niteliktedir. Kadınlar "bir kadın" mahlasını kullanarak şikâyetlerini daha ziyade mahrem olarak dile getirmişlerdir. Örneğin 6 Ekim 1909 tarihli olup bir kadın tarafindan Emniyet-i Umûmiye Müdüriyetine gönderilen mektup buna güzel bir örnek teşkil etmiştir. Mektupta şunlar ifade edilmiştir;

"Halıcıoğlunda Abdûsselam tekkesi karşısında Sarı Hüseyin Efendi'nin ve Yeni mahallede sur üstünde Mösyö Motola(?)'nın ve mezkûr mahalde Tatar Cemil'in ve Bademlikte bir mösyönün (Parisyan(?) gazinosu) taht-1 icarlarındaki kahvehanelerle gazinolarda kumar oynanmaktadır. Kumarbazlar da İstanbul tarafinda işi gücü olup gitmeyenlerle, Cumartesi ve bayram günleri mösyöler ve Pazar günü kayıkçı ve balıkçı Ermenilerden ibarettir ve en ziyade kumar oynayanlar bu kahvelerde firsat buluyorlar. Zira bunların muhbirleri olup zabitan geldiğinde haber veriyorlar. Hatta bu kumar meselesi bu tarafta açıkça terakki etmiştir. Tabi buna da sebep zabıtanın gevşekliği ve kontrolde bulundurmamasıdır. Kazananlar mindelân (?) kahvecilerdir. Ekser bu kahveciler değerli kefâlete rabt olunurlar ise o zaman bu tarafta kumarın önü alınır. Diğer kahvecilere de ibret olur. Af buyurunuz size akıl ögretmiyorum, yalnız bunların korkusu kefâlet meselesi olduğundan arz ediyorum. Ne kadar yazsam ne kadar söylesem bitmez, tükenmez. Vatan namına, hürriyet namına, padişah ve millet başı içün ve Allah rızası içün şu müracaatımı anlayınız. Birtakım kumar yüzünden anaları ve babaları kan ağlayan Hristiyan ve İslamlara merhamet ediniz. Bu tarafta kumarı külliyen men ediniz. İstirhâmâtımızı ke-en-lem-yekün hükmünde tutmayınız. Artık kocalarımızı ve evlatlarımızı bu dertten halas ediniz. Bunlara nizâmat ve kanunun varlığını gösteriniz. Bunlar bir şey yoktur zannediyorlar. Mindelân (?) kahvecilerin tatlı sözlerine inanıyorlar. Onların dili kestirilir ve kanun da görülür ise bizler de mes'ud oluruz. Artık mahvolduk. Bu Hasköy zabıtasının yahud Halıcıŏ̆lu gevşekliği biter. Biraz hükümet görelim. İtimat edelim. Kusurumuzun affiyla ricamızın kabulünü istirham ve niyaz eylerim. Ol bâbda emr-ü irade efendimiz hazretlerinindir. Kadın olmak münasebetiyle kendimi meydana koyamıyorum. Ĕger kumar devam ederse bu sefer de gazete ile size müracaat edeceğim efendim. 23 Eylül 1325, Bir Kadın”. ${ }^{2}$

Mektubun gereği olarak incelemenin yapılması için Beyoğlu Polis Müdüriyetine talimat verilmiştir. Beyoğlu Polis Müdüriyetinin cevabî yazısında bölgede kumar oyunlarının men edilmesi için çalışmalar yapıldığı, söz konusu gazinoya daha

72 BOA, DH.EUM.THR., nr. 91/75, s. 002,003, Tarih: 23 Eylül 1325/6 Ekim 1909. 
önce de baskın düzenlendiği ifade edilmiştir. Şikayet mektubu üzerine yapılan son baskın sırasında da kumar malzemelerine el konulmuş, kumarcılar adliyeye sevk edilmiştir. Polis Müdüriyetinin verdiği bilgiye göre diğer yerlerde yaplan tahkikatlar sonucunda katiyen kumar oynatılmadığı tespit edilmiştir. Kanuna muhalif olarak davrananlara kesinlikle meydan verilmeyeceği de dile getirilmiştir. ${ }^{73}$

Kadınların mektuplarından da anlaşılacağı üzere kumar nedeniyle birçok aile dağılmış, kadın ve çocuklar perişan bir halde kalmıştır. Kadınlar mektuplarında birçok aile ocağının söndügüünü dile getirmişler ve yalvarır halde kumarın engellenmesini talep etmişlerdir. Bu örnekler kumarın sosyal boyutları hakkında önemli veriler oluşturmaktadır. Zira kadınların bu husustaki şikâyet mektupları kumar illetinin toplumu sardı̆̆ının göstergesi olmuştur.

\section{Basında Kumar}

Osmanlı'nın son döneminde kumarın yaygınlaşması ve toplumu tehdit eder hale gelmesi basına da yansımıştır. Tanin, Servet-i Fûnun, Sabah gibi süreli yayınlarda Beyoğlu'nda bazı gazinolarda ve İstanbul'daki kıraathanelerde kumar oynanmakta olduğu, belediye kollarının artık devriye gezmediği, bu durumun da asayişsizliğe neden olduğu yazılmıştır. ${ }^{74}$ Kumarla ilgili olarak Tanin’in 12 Kasım 1908 tarihli nüshasında yer alan "Gazinolarda Kumar" başlıklı yazı ciddi eleştirilere sahiptir. Söz konusu yazıda Beyoğlu bölgesinde bulunan bazı gazinolarda ve İstanbul'daki bazı kıraathanelerde kumarın görünür hale geldiği, basında konuyla ilgili haberler yapılmasına rağmen bunun da fayda sağlamadığı dile getirilmiştir. Yazının devamında "Acaba ne yapmalı?. Bari kumar memnu değildir diye ilan edelim de zabıta da kurtulsun" denilmektedir. ${ }^{75}$ Gazetelerde çıkan bu eleştiriler üzerine 14 Kasım 1908'de Dahiliye Nezareti, Şehremaneti'ne bir yazı göndererek Tanin, Servet-i Fûnun ve Sabah gibi süreli yayınların çeşitli tarihlerde yayınlanan nüshalarında, Beyoğlu'nda bulunan bazı gazinolar ile İstanbul'daki kıraathanelerde kumar oynanmakta olduğu, belediyenin gerekli denetimleri yapmadığı yönündeki eleştirilerin göz önüne alınarak gerekli tedbirlerin ivedilikle alınmasını istemiştir. ${ }^{76}$

73 BOA, DH.EUM.THR., nr. 91/75, s. 003, Tarih: 1 Teşrinievvel 1325/14 Ekim 1909.

74 "Gazinolarda Kumar", Tanin, No: 102, 30 Teşrinievvel 1324/12 Kasım 1908, s. 4: "İşte Şimdi Soruyoruz", Sabah, No: 6872, 30 Teşrinievvel 1324/12 Kasım 1908, s. 1; "Altıncı Daire-i Belediyenin Nazar-1 Dikkatine", Servet-i Fûnun, No: 149, 28 Teşrinievvel 1324/10 Kasım 1908, s. 2; "Sârık", Servet-i Fûnun, No: 149, 28 Teşrinievvel 1324/10 Kasım 1908, s. 4; "Tifo Hastalığı", Servet-i Fûnun, No: 150, 29 Teşrinievvel 1324/11 Kasım 1908, s. 3.

75 "Gazinolarda Kumar", Tanin, No: 102, 30 Teşrinievvel 1324/12 Kasım 1908, s. 4.

76 BOA, DH.MKT., nr. 2659/027, s. 01,01, 05, 01, Tarih: 1 Teşrinisani 1324/14 Kasım 1908. 
İstanbul'da kumarın artışı ile ilgili basında yer alan haberlerin yanında kumarın zararları da anlatılmaya çalışılmıştır. Bu konuda çok sayıda makale yayınlanmış ve hatta edebî eserler verilmiştir. Örneğin Sebiliurreşad'ın Aralık 1913 tarihli nüshasında "Alem-i İslâmı Tehdit Eden Marazlardan: Kumar" başlıklı bir makale buna örnek teşkil etmiştir. Makalede kumarın oldukça yaygın olduğu ve zararları üzerinde durulmuştur. Yazıya göre, istisnalar hariç kumar bütün insanlar arasında ruhi bir hastalıktır. Her kavim ve millet bu hastalıkları kendi anlayışına ve zihniyetine göre muhtelif oyunlar şeklinde ortaya koymuştur. İslamiyet ise her çeşit kumarı haram kılmış ve kumar bulunan her oyun yasaklanmıştır. Ancak buna rağmen İslam ahalisi arasında kumarın yayılması da diğer milletlerden geri kalmamıştır. Şehirler ve kasabalardan başlayarak köylere ve hatta göçebelere kadar her yerde kumar oynanır olmuştur. Kabe'de Peygamberin türbesinin bulunduğu alanlarda, Harem-i Şerif civarında, köylülerin kulübelerinde, kahvehanelerinde, göçebe çadırlarında insanlar bu hastalıktan kıvranmışlardır. Her gün zamanlarının büyük bir kısmını ve akıllarını bu oyunların faydasız neticeleri uğrunda feda etmişlerdir. Bir Müslüman kalbi, hatta alelade bir insan kalbi taşıyan hamiyetli bir kimsenin bütün bunlara acımaması elde değildir. Yazının devamında şu eleştiriye yer verilmiştir; "bizim millet gibi heyet, maişet, faaliyet ve vazifenin ne demek olduğu anlaşllamayan ve zamann kuymetini bilmeyen milletler arasinda bu gibi nefsî ve ruhî hastalkklar toplum ahlakn için büyük olumsuzluklar doğurmaktadır". ${ }^{77}$

I. Dünya Savaşı yıllarında da kumarın toplumsal bir hastalık halini gelmesi basın yoluyla eleştirilmiştir. Mesela 27 Aralık 1917 tarihli Servet-i Fûnun dergisinde yer alan bir yazıda İstanbul'da kumarın tahayyül edilemeyecek noktalara geldiği, kısa zamanda büyük paralar kazanan yeni harp zenginlerinin ihtiraslar peşinde koştukları, kumarın ortadan kaldırılması için yasal düzenlemelerin artık fayda etmediği dile getirilmiştir. ${ }^{78}$

77 "Alem-i İslamı Tehdit Eden Marazlardan: Kumar", Sebilürreşad, G 11, S. 275, Kanunuevvel 1329/Aralık 1913-Ocak 1914, s. 236.

78 "Musahabe Kumar Meselesi”, Servet-i Fûnun. G 53, No: 1373, 27 Kanunuevvel 1333/27 Aralık 1917, s. 342; ayrıca bk. Feyza Kurnaz Şahin, "I. Dünya Savaşı ve Sonrasında Kumarın Yaygınlaşması ve Osmanlı Devleti'nin Aldığı Tedbirler", Selçuk Üniversitesi Edebiyat Fakültesi Dergisi (SEFAD), S. 41, (Yaz 2019), s. 405-426. 


\section{Sonuç}

Arşiv kaynaklarından ve süreli yayınlardan elde edilen veriler genel olarak XIX. yüzyılın ikinci yarısından sonra İstanbul'da ve Osmanlı coğrafyasında kumarın artışına işaret etmektedir. Bunun temel nedeni XIX. yüzyılın köklü siyasal ve ekonomik dönüşümlerin yaşandığı bir süreç olmasıdır. Bu dönemde Kırım Savaşı ve 1877-1878 Osmanlı-Rus Savaşı nedeniyle Osmanlı Devleti ciddi bir mali kriz içerisine girmiştir. Dış borçlanma ve bilahare borçların ödenememesi sonucunda Muharrem Kararnâmesi imzalanmış ve Düyûn-u Umûmiye kurularak Osmanlı gelirlerine el konulmuştur. Onlarca yıldır süren savaşlar sonrası, birçok işyeri kapanmış, işsizlik had safhaya ulaşmış, üretken erkek nüfus azalmış, göçler nedeniyle toplumsal buhran artmıştır. Devletin içinde olduğu siyasal ve finansal kriz toplum hayatını derinden etkilemiş, normal zamanlarda yapılması uygun görülmeyen fiiller ve suç sayılan eylemler aleni hale gelmiştir.

II. Meşrutiyet döneminde yaşanan sancılar toplumsal çözülmeyi hızlandırmıştır. Bu dönemde liberal düşünce ve özgürlükçü ortam ilk başlarda umut verici olsa da bu durum uzun sürmemiştir. 31 Mart Vakası ve II. Abdülhamid'in tahtan indirilmesi ve ardından yaşanan siyasal krizler, İttihat ve Terakki'nin baskıcı yönetimi, kısa ömürlü hükümetler, ayaklanmalar ve ciddi toprak kayıpları yaşanmıştır. Dış borçlanmanın giderek artması, yaşanan mali krizler toplumsal yapıyı sarsmıştır. II. Meşrutiyet döneminde yaşanan sosyal ve ekonomik sıkıntılar nedeniyle kumar artık toplumsal bir hastalık haline gelmiş, sadece kahvehanelerde oynanan bir oyun olmaktan çıkmıs, evlere kadar sirayet etmiştir. Kumarın yaygın hale gelmesi aile ve toplumu derinden sarsmiştır.

Osmanlı arşiv kaynaklarından izlendiği kadarıyla Osmanlı hükümeti kumara karŞ1 tavizsiz bir yaklaşım sergilemiş, kumarın önlenmesi için gerekli yasal düzenlemeleri hayata geçirmiştir. Bu anlamda öncelikli olarak 1851 ve 1858 tarihli Ceza Kanununa kumarın suç olduğuna ilişkin esaslar konulmuştur. Yine 1869 Askerî Ceza Kanunnâmesine ve 1907 tarihli Polis Nizamnâmesine de kumarla ilgili esaslar eklenmiş, ancak kumarın cezalandırılması kumarın engellenmesinde rasyonel bir etki yaratmamıştır.

$\mathrm{Bu}$ tedbirlere rağmen XX. yüzyılın başlarında kumar çeşitli mekanlarda aleni olarak oynanmaya başlamıştır. Halk, kumarın yaygınlaşmasının sorumlusunu ararken, kolluk kuvvetlerinin gerekli denetimi yapmaması ve ihmali nedeniyle kumarın yaygınlaştı̆̆ına kanaat getirmiştir Hatta daha sert bir söylemle polisin ahlaksızlığa göz yumduğuna dair dönemin basınında yazılar kaleme alınmıștır. 
Kumarın yaygın hale gelmesi kadınları da rahatsız etmiştir. Emniyet-i Umûmiye Müdüriyetine "Kumarzedegân Kadınlar" imzasıyla mektuplar gönderilerek hususi hanelerde kumar oynatıldığı, birçok namuslu ailelerin bu nedenle perişan oldukları ifade edilerek kumarın engellenmesi istenmiştir. Kadınlar arasında kolluk kuvvetleri tarafindan kumara müsamaha gösterildiğine dair yaygın bir kanaatin varlığı dikkat çekicidir.

Kumar, I. Dünya Savaşı yıllarında daha da yayılmıştır. Bu dönemde İstanbul'da karaborsacılık ve istifçilikle yüksek gelirler elde eden harp zengini kişiler sefâhate düşmüştür. Bu kesimin eğlence düşkünlüğü toplumsal ahlakı zaafa uğratmış, İstanbul bir yandan eğlencenin diğer yandan sefaletin yaşandığı bir şehir görüntüsüne bürünmüsstür.

Sonuç olarak şunu söyleyebiliriz ki Osmanlı'nın son döneminde devletin içinde bulunduğu siyasal, sosyal ve ekonomik buhran, hızlı ve köklü değişimler, toplumsal hayatta bazı çözülmelere neden olmuştur. Bu nedenle fuhuş, içki ve kumar gibi alışkanlıklar da yaygınlık kazanmıştır. Devlet bu tehlikeyi görmüş ve çeşitli tedbirler alma yoluna gitmiştir. Ancak kumarı önlemek amacıyla alınan tedbirler ve yasal düzenlemeler kesin bir çözüm getirememiştir. 


\section{KAYNAKLAR}

\section{Arşiv Belgeleri}

\section{Cumhurbaşkanlığı Devlet Arşivleri Başkanlığı Osmanlı Arşivi (BOA)}

Babıali Evrak Odası Evrakı (BEO),

Dahiliye Emniyet-i Umûmiye Emniyet Şubesi Evrakı (DH.EUM.EMN.),

Dahiliye Emniyet-i Umûmiye Evrak Odası Kalemi Evrakı (DH.EUM.VRK.),

Dahiliye Emniyet-i Umûmiye Tahrirat Kalemi Evrakı (DH.EUM.THR.),

Dahiliye Nezareti Emniyet-i Umûmiye Kısm-1 Adli Kalemi (DH.EUM.KADL.),

Dahiliye Nezareti Hukuk Evrakı (DH.H.),

Dahiliye Nezareti İdare Evrakı (DH.İD.),

Dahiliye Nezareti Mektubî Kalemi (DH.MKT.),

Divan (Beylikçi) Kalemi Defterleri (A.DVN.),

Maarif Mektubi Kalemi (MF.MKT.),

Şura-yı Devlet Evrakı (ŞD.),

Yıldız Perakende Evrakı Askeri Maruzat (Y.PRK.ASK.),

Yıldız Perakende Evrakı Mâbeyn Başkitâbeti (Y.PRK.BŞK.),

Ylldız Resmi Maruzat (Y.A.RES.).

\section{Resmî Yayınlar}

"Ceza Kanunnâme-i Hümâyunu” 28 Zilhicce 1274/9 Ağustos 1858, Dïstur, Tertip I, C I, Matbaa-yı Amire, 1289.

Düstur, Cûz-i Rabi, Maarif Nezaret-i Celilesinin Ruhsatıyla, Matbaayı Amire, İstanbul 1295.

"Polis Nizamnâmesi", Düstur, Tertip I, Mütemmim, Hilal Matbaası, 15 Muharrem 1269-8 Recep 1325, Dersaadet Zilkade 1335.

\section{Telif Eserler ve Süreli Yayınlar}

Ahmed Lütfi, Mir'at-ı Adalet Yahud Tarihçe-i Adliye-i Devlet-i Aliye, Naşiri: Kitapcı Ohannes, Matbaa-i Nişan Berberyan, İstanbul 1304. 
Akgündüz, Ahmet, Mukayeseli İslam ve Osmanl Hukuku Külliyatı, Dicle Üniversitesi Hukuk Fakültesi Yay., Diyarbakır 1986.

"Alem-i İslamı Tehdit Eden Marazlardan: Kumar", Sebilürreşad, G 11, S. 275, Kanunuevvel 1329/Aralık 1913-Ocak 1914, s. 236.

"Altıncı Daire-i Belediyenin Nazar-1 Dikkatine", Servet-i Fûnun, No: 149, 28 Teşrinievvel 1324/10 Kasim 1908, s. 2.

Aydın, Mehmet Akif, "Osmanlı Ceza Hukuku”, İslam Ansiklopedisi, G 7, Türkiye Diyanet Vakfi Yayını, İstanbul 1993, s. 478-482.

Aysal, Necdet, 'Kırım Savaşı'ndan Lozan Barış Antlaşmasıı'na Osmanlı Dış Borçlarının Tarihsel Gelişim Süreci (1854-1923)", Ankara Üniversitesi Türk Inkılâp Tarihi Enstitüsü Atatürk Yolu Dergisi (Lozan Antlaşması Özel Sayısı), S. 53, (2013), s. $1-28$.

Ayverdi, İlhan, Misalli Büyük Türkçe Sözlük, C 2, Kubbealtı Lugati, 4. bs., İstanbul 2011.

Bardakoğlu, Ali, "Kumar", İslam Ansiklopedisi, C 26, Türkiye Diyanet Vakfı Yayını, İstanbul 2002, s. 364-367.

Bezaz, Yurda Güven, Geçmişten Günümüze Haberleşme ve PTT Tarihi, Türkiye Haber-İş Sendikası Yay., Ankara (2007?).

Çetinkaya, Canan - Kasalak, Kadir, "Cumhuriyet'in İlk Yıllarında Piyangoculuk", Sobider Sosyal Bilimler Dergisi, Yıl: 2, S. 5, (Aralık 2015), s. 467-481.

Çetinkaya, Canan, Osmanlı'nın Son Dönemleri ve Cumhuriyetin İlk Yillarnnda Şans Oyunlan, (Basılmamış Yüksek Lisans Tezi), Süleyman Demirel Üniversitesi Sosyal Bilimleri Enstitüsü, Isparta 2015.

Demir, Tanju, "Salih Zeki ve Ecnebi Postaneleri’nin Kaldırılması Konusundaki Görüşleri”, Osmanh Bilim Araştırmalan, C VII/1 (2005), s. 169-185.

Demirtaş, Mehmet, “Osmanlıya Gelen Kırım ve Kafkasya Göçmenlerinin Sorunları", Bilig, S. 57, (Bahar 2011), s. 17-44.

Dikici, Ali, “II. Meşrutiyet’ten Gumhuriyet'e Miras Kalan İç Güvenlik Anlayışı ve Polis Teşkilatı", Türk İdare Dergisi, S. 479, (Aralık 2014), s. 91-122.

Faroqhi, Suraiya, Osmanl Kültürü ve Gündelik Yaşam Ortaçăğdan Yirminci Yüzynla, Tarih Vakfi Yurt Yayınları, 4. bs., İstanbul 2002. 
"Gazinolarda Kumar", Tanin, No: 102, 30 Teşrinievvel 1324/12 Kasım 1908, s. 4.

Gündüz, Mustafa, II. Meşrutivet'in Klasik Paradigmalarn, İçtihad, Sebilü’r Reşad ve Türk Yurdu'nda Toplumsal Tezler, Lotus Yayınları, Ankara 2007.

Halil Fahreddin, "Bizde Ahlak", Sebilürreşad, 30 Ağustos 1328 (12 Eylül 1912), C 9, Adet: 28-210, s. 31.

Işın, Ekrem, İstanbul'da Gündelik Hayat, Yapı Kredi Yayınları, İstanbul 1999.

“İşte Şimdi Soruyoruz", Sabah, No: 6872, 30 Teşrinievvel 1324/12 Kasım 1908, s. 1 .

Kurnaz Şahin, Feyza, "I. Dünya Savaşı ve Sonrasında Kumarın Yaygınlaşması ve Osmanlı Devleti'nin Aldığı Tedbirler", Selçuk Üniversitesi Edebiyat Fakültesi Dergisi (SEFAD), S. 41, (Yaz 2019), s. 405-426.

"Memnûiyet", Sabah, Yirmi İkinci Sene, No: 7647, 24 Kanunuevvel 1326/6 Ocak 1911, s. 2.

"Musahabe Kumar Meselesi”, Servet-i Fûnun. C 53, No: 1373, 27 Kanunuevvel 1333/27 Aralık 1917, s. 342.

Osmanh Belgelerinde Kirm Savaşı (1853-1856), Yay. Haz. Kemal Gurulkan vd., Devlet Arşivleri Genel Müdürlüğü Yayınları, Ankara 2006.

Öner, Senem, Çeviri Yoluyla Kanun Yapmak: 1858 Tarihli Osmanh Ceza Kanunu'nun 1810 Tarihli Fransiz Ceza Kanunu'ndan Çeorilmesi, (Basılmamış Doktora Tezi), Yıldız Teknik Üniversitesi Sosyal Bilimler Enstitüsü, İstanbul 2013.

Öztürk, Yeter, XIX. Yüzynl Arşiv Belgelerine Göre Osmanh Devleti’nde İcki ve Yasaklarn, (Basılmamış Yüksek Lisans Tezi), Ordu Üniversitesi Sosyal Bilimler Enstitüsü, Ordu 2017.

Pamuk, Şevket, Osmanl Ekonomisinde Bağımllhk ve Büyüme 1820-1913, Tarih Vakfi Yurt Yayınları, 2. bs., İstanbul 1994, s. 1-7.

Pamuk, Şevket, Osmanh İmparatorluğu’nda Paranın Tarihi, Tarih Vakfi Yurt Yayınları, İstanbul 1999.

Pamuk, Şevket, Osmanh-Türkive İktisadi Tarihi 1500-1914, İletişim Yayınları, 8. bs., İstanbul 2013.

Quataert, Donald, Osmanh Devleti'nde Avrupa Iktisadi Taynlım ve Direniş 1881-1908, İletişim Yay., İstanbul 2017. 
"Sârık", Servet-i Fûnun, No: 149, 28 Teşrinievvel 1324/10 Kasım 1908, s. 4.

"Silah Atmak Yasaktır”, Tanin, Üçüncü Sene, No: 841, 24 Kanunuevvel 1326/6 Ocak 1911, s. 5.

Şahin, Gürsoy, İngiliz Seyahatnamelerinde Osmanl Toplumu ve Türk Imajı, Gökkubbe Yayınları, İstanbul 2017.

Şentop, Mustafa, "Tanzimat Dönemi Kanunlaştırma Faaliyetleri Literatürü", Türkiye Araştırmalan Literatür Dergisi, C 3, S. 5, (2005), s. 647-672.

Tabakoğlu, Ahmet, Osmanlı Mali Tarihi, Dergah Yayınları, İstanbul 2016.

Tabakoğlu, Ahmet, Türkiye İktisat Tarihi, Dergah Yayınları, 11. bs., İstanbul 2012.

TDK Türkçe Sözlük, Türk Dil Kurumu Yayınları, 11. bs., Ankara 2011, s. 1524.

"Tifo Hastalı̆̆gı", Servet-i Fûnun, No: 150, 29 Teşrinievvel 1324/11 Kasım 1908, s. 3.

Toprak, Zafer, Türkiye’de Milli İktisat 1908-1918, Doğan Kitap, İstanbul 2012.

Tuncel, Metin, "Yalova", İslam Ansiklopedisi, C 43, Türkiye Diyanet Vakfi Yay. İstanbul 2013, s. 306-308.

Tunç, Şafak, Osmanl Payitahtında Kahvehane ve Kahvehane Kültürünün Keri, (Basılmamış Yüksek Lisans Tezi), İstanbul Üniversitesi Sosyal Bilimler Enstitüsü, İstanbul 2014.

Tunçay, Mete, Türkiye'de Piyango Tarihi ve Milli Piyango İdaresi, Milli Piyango İdaresi Yayını, Ankara 1993.

Türk Hukuk Lügati, haz.: Türk Hukuk Kurumu, Başbakanlık Mevzuatı Geliştirme ve Yayın Genel Müdürlüğü Yayınları, 3. bs., Ankara 1991, s. 206-207.

Varlı, Arzu - Koraltürk, Murat, "II. Meşrutiyet'ten Erken Cumhuriyet'e Milli İktisadın Sürekliliği ve İzmir İktisat Kongresi”, Çağdaş Türkiye Tarihi Araştırmalan Dergisi (ÇTTAD), G IX/20-21, (Bahar-Güz 2010), s. 127-142.

Yakut, Kemal - Yetkin, Aydın, 'II. Meşrutiyet Dönemi’nde Toplumsal Ahlak Bunalımı: Fuhuş Meselesi”, Kebikeç, Yıl 16, S. 31, (2011), s. 275-307.

Yolal, Mesut, Osmanl Devletinde Şans Oyunlan ve Kumar (1800-1923), (Basılmamış Doktora Tezi), Gaziantep Üniversitesi Sosyal Bilimler Enstitüsü, Gaziantep 2018. 


\section{EKLER}

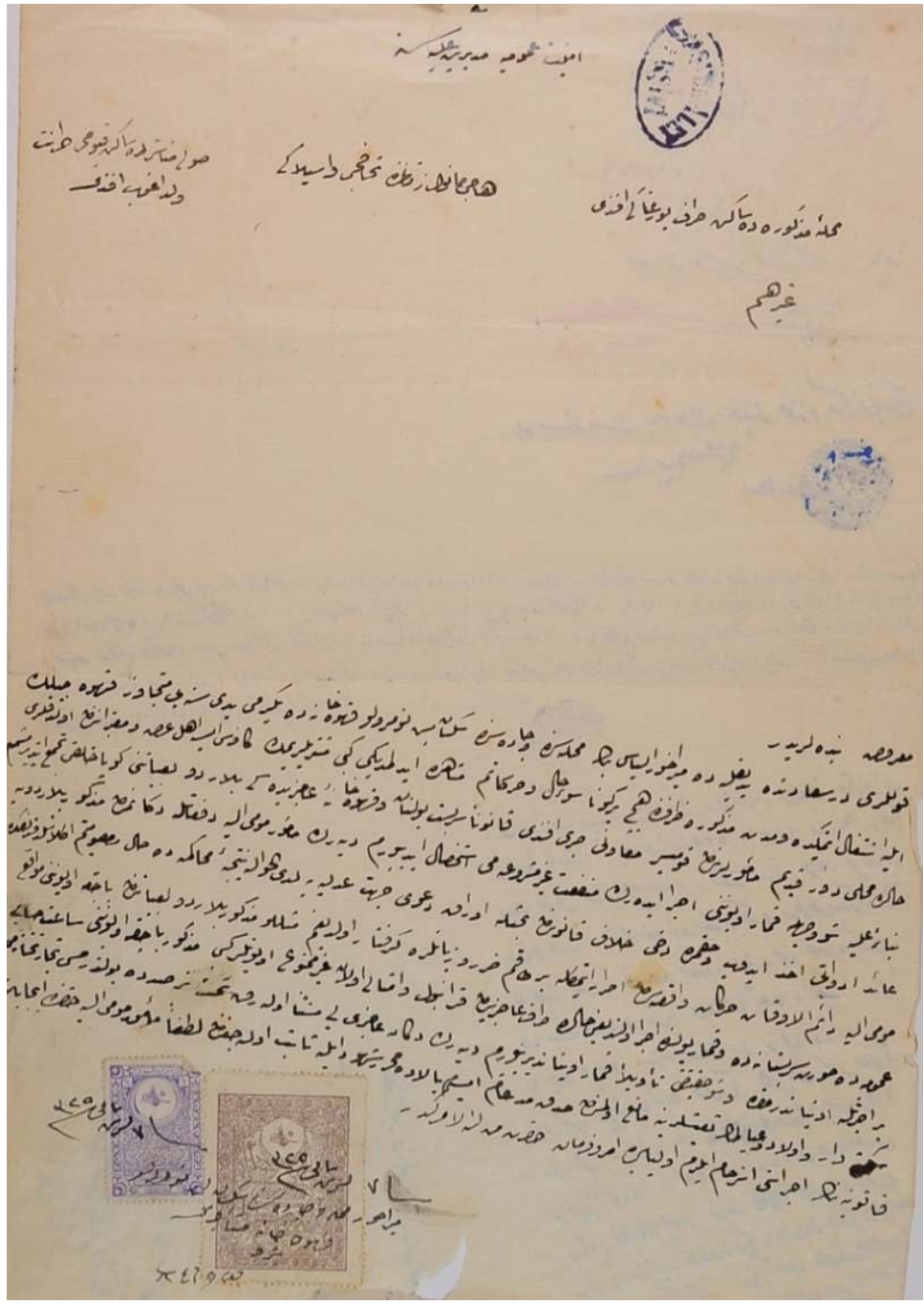

Ek 1: Yedikule'de Kahvecilik Yapan Hacı Stefan'ın Kahvehanesinde Kumar Oynanması Hakkında. BOA, DH.EUM.THR., nr. 14/50, s. 002, Tarih: 7 Teşrinisani 1325/20 Kasım 1909. 